\title{
Quantification of phytochemicals and in vitro antioxidant activities from various parts of Euphorbia neriifolia Linn.
}

\author{
Priya Chaudhary, Pracheta Janmeda* \\ Department of Bioscience and Biotechnology, Banasthali Vidyapith, Rajasthan-304022, India.
}

\begin{tabular}{l} 
ARTICLE INFO \\
\hline Article history: \\
Received on: August 09, 2021 \\
Accepted on: October 21, 2021 \\
Available online: February 15, 2022
\end{tabular}

Keywords:

Antioxidant activity, Chelation assay, Correlated, Euphorbia neriifolia, Phytochemical content, Scavenging activity, Spectrophotometric

\begin{abstract}
This study aims to investigate the phytochemical content and antioxidant activity of the leaf, stem, latex, and bark of Euphorbia neriifolia (EN) Linn. using the solvent extraction method with petroleum ether, benzene, chloroform, ethyl acetate, methanol, and aqueous extracts. Total tannin content, total saponin content, total flavonoid content, total phenol content, and total flavonol content were investigated using spectrophotometric equivalents of the standards, tannic acid, quillaja, quercetin, gallic acid, and rutin, respectively. The EN extracts of various parts were screened for potential antioxidant activities by hydrogen peroxide scavenging assay $\left(\mathrm{H}_{2} \mathrm{O}_{2}\right)$, ferric ion reducing antioxidant power assay (FRAP), 2,2-diphenylpicrylhydrazyl assay (DPPH), metal chelation assay, nitric oxide (NO), and superoxide ( $\mathrm{SO}$ ) scavenging methods. The quantitative analysis of phytochemicals from EN revealed the presence of tannins, saponins, flavonoids, phenols, and flavonols in considerable amounts. The in vitro antioxidant assay of EN determined that the leaf, stem, latex, and bark have prominent antioxidant potential. The results showed that all the plant parts possessed antioxidant properties which were strongly correlated with the phytoconstituents. From the present study, it can be concluded that the mean content of phytochemicals in the case of EN leaf is greater than the stem, latex, and bark of the plant and this may have contributed to its great antioxidant properties. This may also justify the frequent use of the leaf more than the stem, latex, and bark in the traditional medicinal systems for the cure of bronchial infections, abdominal swellings, inflammation, pain, and tumor.
\end{abstract}

\section{INTRODUCTION}

Living cells may produce reactive oxygen species (ROS) including hydrogen peroxide, hydroxyl radicals, and superoxide anion $\left(\mathrm{O}_{2}^{-}\right)$as a side product in the biochemical and physiological processes $[1,2]$. However, when the excess concentration of ROS is not eliminated, it may cause damage to cellular components and impair their functioning [3]. They also play a critical role in aging and other age-related disorders such as Parkinson's, Alzheimer's, atherogenesis, hypertension, and cancer diseases [4].

The most effective way to fight against these degenerative diseases is to use antioxidants. Antioxidants are those substances that can obstruct and control the oxidation of an oxidizable substrate [5].

\footnotetext{
*Corresponding Author

Pracheta Janmeda, Department of Bioscience and Biotechnology,

Banasthali Vidyapith, Rajasthan-304022, India.

E-mail: pracheta@banasthali.in
}

Endogenous antioxidants are produced inside the living organisms and repair the damage caused by radicals internally with the help of the cell regeneration system, while exogenous antioxidants are taken from sources present outside the living body such as diet which stimulate cell repair machinery externally [6]. The increasing need to complement the function of endogenous antioxidants has led to the supplementation by exogenous sources [7]. Nowadays, exogenous sources are the widespread research topics, perhaps due to their fewer side effects, cheap cost, and readily availability than the synthetic ones [8].

Considering the complementary strategies and available alternatives, medicinal plants hold a better place in providing easily accessible, affordable, and safer therapies for ROSrelated diseases [9]. The antioxidant potential of medicinal plants has been observed to play an important role in lowering the risk of various diseases [10]. There is a broad diversity of 
phytocompounds, mainly secondary metabolites, usually present and isolated from medicinal plants and studies have revealed that these metabolites have antiviral, antitumor, anti-inflammatory, analgesic, antibacterial, anticancer, and various other activities from a lesser to a greater extent [11-13]. Well-known examples of these phytocompounds include terpenoids, nitrogen compounds, tannins, cyanogen glycosides, saponins, phenolic glycosides, phenols, and flavonoids [14]. Phenolic compounds consist of tannins, flavonoids, and phenols which appear to be the major and most effective antioxidants as they can scavenge free radicals, prevent lipid peroxidation, and chelate metal ions. Apart from this, non-phenolic compounds also represent an abundant and important class of free radical scavengers inside the host organism [2].

EN Linn. (Euphorbiaceae), is a xerophytic succulent plant that is utilized as a folk medicine for various disorders according to the indigenous resources of Japan, China, Philippines, Malaysia, Thailand, Burma, and India [15]. It is an erect, and fleshy plant with oval-shaped leaves and unarticulated stems and branches [16]. It is majorly distributed in the subtropical and tropical regions of Asia and is popularly known by the name of "Thohar" and "Sindhu" in the Hindu scripture [17,18]. Different parts (such as leaves, stem, latex, bark, roots, and fruits) of this medicinal plant contain a wide range of secondary metabolites (steroid, polyphenol, saponin, tannin, triterpenoid, alkaloid, and flavonoid) which are useful to cure various human ailments such as bleeding piles, fever, anemia, inflammation, leukoderma, tumors, bronchitis, abdominal troubles, and enlargement of the spleen [19-22]. EN is a good choice to be used as a source of efficient therapeutics since the availability and the propagation of this plant is easy and cheap.

Although extensive work on secondary compounds and their total content in EN leaf has been carried out, the data on other parts of this plant are still incomplete and insufficient. Hence, this study aimed to evaluate the fluctuations in total tannin (TT), total saponin (TS), total flavonoid (TF), total phenol (TP), and total flavonol (TFL) content in extracts of EN leaf, stem, latex, and bark. Antioxidant activity was evaluated by hydrogen peroxide $\left(\mathrm{H}_{2} \mathrm{O}_{2}\right)$, ferric ion-reducing antioxidant power assay (FRAP), 2,2-diphenylpicrylhydrazyl (DPPH), metal chelating, NO, and SO methods. The relationships between antioxidant activities and contents of TT, TS, TF, TP, and TFL, measured in the plant samples, were discussed to provide a scientific basis for optimal usage of EN leaf, stem, latex, and bark.

\section{MATERIALS AND METHODS}

\subsection{Reagents and Standards}

Trichloroacetic acid, thiobarbituric acid, phenazine methosulfate (PMS), linoleic acid, nitro blue tetrazolium (NBT), DPPH, linoleic acid, rutin, Gallic acid, ferrozine, Folin-Ciocalteu's reagent, potassium persulfate, quercetin, $(+)$-catechin, ferric chloride $\left(\mathrm{FeCl}_{3}\right)$, aluminum chloride, ascorbic acid, Gallic acid, sodium carbonate $\left(\mathrm{Na}_{2} \mathrm{CO}_{3}\right)$, sodium acetate, sodium hydroxide $(\mathrm{NaOH})$, sodium nitrite $\left(\mathrm{NaNO}_{2}\right)$, tannic acid (TA), sodium tungstate, phosphomolybdic acid, phosphoric acid, vanillin, sulfuric acid, ethylenediaminetetraacetic acid (EDTA), butylated hydroxytoluene (BHT), hydrochloric acid, 2,4,6-tri (2-pyridyl)-
S-triazine (TPTZ), $\mathrm{H}_{2} \mathrm{O}_{2}$, sodium nitroprusside, 'Griess' reagent, disodium hydrogen phosphate $\left(\mathrm{Na}_{2} \mathrm{HPO}_{4}\right)$, and sodium dihydrogen phosphate $\left(\mathrm{NaH}_{2} \mathrm{PO}_{4}\right)$; other solvents were of analytical grade and were procured from Sigma Aldrich (Germany).

\subsection{Preparation of Extracts from Powdered Plant Material}

Preparation of the extracts was carried out by hot extraction method using the Soxhlet apparatus. Finely ground powder of the plant material was packed inside the porous filter paper and placed inside the extraction chamber. The selected solvents were added into the round bottom flask, evaporated, and allowed to reach the condenser where it condenses and drips down into the extraction chamber and extracts the plant components by coming in contact with the powder. The whole process continued sequentially until all the extracts were prepared. After extraction, the extracts were stored at $4^{\circ} \mathrm{C}$ in an airtight container for further evaluation [23].

\subsection{Quantification of Phytochemicals}

\subsubsection{Total tannin content}

In order to estimate the content of tannin, a solution (Folin-Denis' reagent) of $50 \mathrm{ml}$ phosphoric acid, $30 \mathrm{~g}$ phosphomolybdic acid, and $100 \mathrm{mg}$ sodium tungstate in $750 \mathrm{ml}$ of distilled water was allowed to reflux for a time period of 2 hours and further diluted to $250 \mathrm{ml}$. A calibration curve with TA standard $(1 \mathrm{mg} / \mathrm{ml})$ was also prepared in $10 \mathrm{ml}$ of methanol. An aliquot of $0.5 \mathrm{ml}$ of different extracts and standard was added to the $0.5 \mathrm{ml}$ of methanol in a test tube. This was followed by the addition of $0.5 \mathrm{ml}$ of freshly prepared Folin-Denis' reagent. Then to the solution, $2 \mathrm{ml}$ of $20 \%$ sodium carbonate $\left(\mathrm{Na}_{2} \mathrm{CO}_{3}\right)$ was added, covered, vortexed, and incubated for 1 minute in a water bath. The absorbance of the reaction mixture was recorded at $700 \mathrm{~nm}$. The quantity of tannin was estimated in triplicate and determined as mg TA equivalent per gram dry matter (DM) as described by Haile and Kang [24].

\subsubsection{Total saponin content}

The total saponin content was determined using the colorimetric method of Le et al. [25] with some moderations. To $0.25 \mathrm{ml}$ of the properly diluted leaf, stem, latex, and bark extract samples, $0.25 \mathrm{ml}$ of $8 \%$ vanillin in methanol (w/v) was added, followed by the addition of $2.5 \mathrm{ml}$ of $72 \%$ sulfuric acid $\left(\mathrm{H}_{2} \mathrm{SO}_{4}\right)$. Then the test tubes were covered, vortexed, and incubated for 15 minutes at $60^{\circ} \mathrm{C}$ and allowed to cool down further. In this method, sulfuric acid-oxidized saponin was reacted with vanillin to produce a characteristic reddish purple color, whose absorbance was taken at $560 \mathrm{~nm}$. A standard curve of quillaja $(10-1,000 \mu \mathrm{g} / \mathrm{ml})$ was constructed to evaluate the concentration of saponin in the samples. The following outcomes were represented as mg quillaja (QJ) equivalents per gram dry matter.

\subsubsection{Total flavonoid content}

Determination of total flavonoid content was carried out by using the aluminum colorimetric method with slight moderations, as described by Sankhalkar and Vernekar [26]. An aliquot $(0.5 \mathrm{ml})$ of the standard solution of quercetin and different extracts was added to the test tube containing $0.5 \mathrm{ml}$ distilled water. To the test tubes, 
$0.3 \mathrm{ml}$ of $5 \%$ sodium nitrite $\left(\mathrm{NaNO}_{2}\right)$ was added and incubated at $25^{\circ} \mathrm{C}$ for 5 minutes. This was followed by the immediate addition of $0.3 \mathrm{ml}$ of $10 \%$ aluminum chloride $\left(\mathrm{AlCl}_{3}\right)$ and $2 \mathrm{ml}$ of sodium hydroxide $(\mathrm{NaOH})$, whose absorbance was recorded at $510 \mathrm{~nm}$. The outcomes of total flavonoid content were expressed as $\mathrm{mg}$ quercetin $(\mathrm{QR})$ equivalents per gram of dry matter.

\subsubsection{Total phenol content}

The content of phenols was determined by the Folin-Ciocalteu method described by Rebaya et al. [27] using Gallic acid as the standard. Different extract samples $(1 \mathrm{mg} / \mathrm{ml})$ were mixed with 5 $\mathrm{ml}$ of methanol. This was followed by the addition of $1 \mathrm{ml}$ of $20 \%$ sodium carbonate and $1 \mathrm{ml}$ of the Folin-Ciocalteu reagent. The mixture was allowed to stand at $40^{\circ} \mathrm{C}$ for 30 minutes in a water bath. After 30 minutes, the absorbance was recorded at $765 \mathrm{~nm}$ using a UV-Visible spectrophotometer. All the tests were carried out in triplicate and the phenolic content was represented as mg of gallic acid (GLA) equivalents per g dry matter.

\subsubsection{Total flavonol content}

Total flavonol content was estimated since flavonol is considered to be the major fraction responsible for the antioxidant activity. To $2 \mathrm{ml}$ of properly diluted leaf, stem, latex, and bark extract samples in methanol, $2 \mathrm{ml}$ of $2 \%$ aluminum chloride $\left(\mathrm{AlCl}_{3}\right)$ in methanol and $3 \mathrm{ml}$ of $50 \mathrm{~g} / 1$ sodium acetate were added. The mixture was allowed to incubate for $2.5 \mathrm{hrs}$ at $20^{\circ} \mathrm{C}$ and their absorbance was measured at $440 \mathrm{~nm}$. A standard curve of rutin (RUT) in methanol $(1 \mathrm{mg} / \mathrm{ml})$ was prepared to determine the content of flavonol in the sample and the results were expressed as the mg RUT equivalent (q) per g dry matter [28].

\subsection{Evaluation of In vitro Antioxidant Activity}

\subsubsection{Hydrogen peroxide scavenging activity}

The scavenging ability of the EN extracts for hydrogen peroxide was evaluated according to the method described by Bhatti et al. [29], and the results were expressed as $\mu \mathrm{g} / \mathrm{ml}$. The hydrogen peroxide solution was prepared by mixing the $20 \mathrm{mM}$ of $\mathrm{H}_{2} \mathrm{O}_{2}$ into $50 \mathrm{mM}$ of $\mathrm{pH} 7.4$ phosphate buffer. Aliquots of $0.1 \mathrm{ml}$ of extract samples $(10-1,000 \mu \mathrm{g} / \mathrm{ml})$ were taken into the test tubes and their volume is made up by the addition of $0.4 \mathrm{ml}$ of methanol or phosphate buffer $(50 \mathrm{mM})$. This was followed by the addition of $0.6 \mathrm{ml}$ of hydrogen peroxide solution. The test tubes were shaken and the absorbance of samples was recorded after 40 minutes at 230 $\mathrm{nm}$ against the blank. Phosphate buffer without the involvement of hydrogen peroxide served as the blank and ascorbic acid was used as the positive control. The percentage of the scavenging activity of extracts (in triplicate) was calculated by the following formula:

$$
\% \mathrm{H}_{2} \mathrm{O}_{2} \text { scavenging activity }=\left[\left(A_{0}-A_{1}\right) / A_{0}\right] \times 100
$$

where $A_{0}$ is the absorbance of the control and $A_{1}$ is the absorbance of the sample.

\subsubsection{Ferric-reducing antioxidant power assay}

The antioxidant ability of the EN extracts was determined by the use of ferric-reducing antioxidant power assay. The FRAP reagent preparation involves $10 \mathrm{mM}$ of TPTZ in $40 \mathrm{mM}$ of $\mathrm{HCl}, 20 \mathrm{mM}$ of $\mathrm{FeCl}_{3}$, and $300 \mathrm{mM}$ of acetate buffer $(\mathrm{pH}=3.6)$ in the ratio of 1:1:10. The different concentrations of the sample solutions and $1 \mathrm{ml}$ of FRAP reagent were added to the test tube and their absorbance was recorded at $593 \mathrm{~nm}$ after the incubation period of 30 minutes at $37^{\circ} \mathrm{C}$ in a water bath. A potential candidate carried out the reduction of ferric ion $\left(\mathrm{Fe}^{3+}\right)$ to ferrous ion $\left(\mathrm{Fe}^{2+}\right)$ and later developed a blue color complex of $\mathrm{Fe}^{2+} / \mathrm{TPTZ}$, which raised the absorption at $593 \mathrm{~nm}$. The results were expressed as $\mu \mathrm{M} \mathrm{Fe}$ (II) $/ \mathrm{g}$ and compared with the standard BHT [30].

\subsubsection{DPPH radical scavenging assay}

The free-radical scavenging potential of leaf, stem, latex, and bark extracts was determined by a decrease in the absorbance of methanolic solution of DPPH [31]. A stock solution of DPPH was prepared by dissolving $33 \mathrm{mg}$ of DPPH in 11 of methanol and then stored under dark condition. To $1 \mathrm{ml}$ of different concentrations of extracts $(10-1,000 \mu \mathrm{g} / \mathrm{ml})$ and ascorbic acid standard in methanol, $5 \mathrm{ml}$ of the DPPH solution was added, shaken, and stored under dark for 20 minutes at $27^{\circ} \mathrm{C}$. After incubation, absorbance was recorded at $517 \mathrm{~nm}$ using a UV-Visible spectrophotometer. Scavenging potential was expressed as the percentage of inhibition, which was calculated by the following formula:

$$
\% \text { inhibition }=\left[\left(A_{0}-A_{1}\right) / A_{0}\right) \times 100,
$$

where $A_{\mathrm{o}}$ is the control absorbance and $A_{1}$ is the test sample absorbance.

\subsubsection{Metal chelation activity}

The chelation of ferrous ions by the different extracts of leaf, stem, latex, and bark of EN and by the EDTA standard was determined by the method described by Bariş et al. [32]. Different concentrations of test samples and standard $(10-1,000 \mu \mathrm{g} / \mathrm{ml})$ were mixed with $3.7 \mathrm{ml}$ of the methanol solution. Then the mixture was treated with $0.1 \mathrm{ml}$ of $2 \mathrm{mM} \mathrm{FeCl}_{2}$ and $0.2 \mathrm{ml}$ of $5 \mathrm{mM}$ ferrozine and allowed to stand for 10 minutes at room temperature. When the reaction reached equilibrium, its absorbance was recorded spectrophotometrically at $562 \mathrm{~nm}$. The percentage of ferrous ion chelation was calculated as follows:

$$
\begin{gathered}
\% \text { Chelating activity }=[1-(\text { Absorbance of test sample } / \\
\text { Absorbance of control })] \times 100
\end{gathered}
$$

\subsubsection{Nitric oxide scavenging activity}

The nitric oxide radical scavenging potential of different fractions was determined by the Griess reaction as reported by Corpuz et al. [33]. Sodium nitroprusside (10 mM, $1.5 \mathrm{ml})$ solution was prepared in $20 \mathrm{mM}$ of phosphate buffer $(\mathrm{pH} 7.4)$ and was added to $0.5 \mathrm{ml}$ of different concentrations of test extracts and standard. Furthermore, the reaction mixture was allowed to incubate for 150 minutes at $25^{\circ} \mathrm{C}$. After incubation, $0.5 \mathrm{ml}$ of the aliquot was removed from the reaction mixture and $0.5 \mathrm{ml}$ of the Griess reagent was added into it and absorbance was recorded spectrophotometrically at $546 \mathrm{~nm}$. Sodium nitroprusside in phosphate buffer solution (PBS) was used as the control and ascorbic acid was utilized as the reference standard. The 
scavenging activity of ascorbic acid and fractions was calculated according to the following formula:

$\%$ Nitric oxide scavenging activity $=\left[\left(A_{0}-A_{1}\right) / A_{0}\right] \times 100$

where $A_{\mathrm{o}}$ is the control absorbance and $A_{1}$ is the test sample absorbance.

\subsubsection{Superoxide scavenging activity}

The ability of the extracts to scavenge superoxide radicals was assessed by the NBT reduction method described by Yang et al. [34] with little moderations. Aliquots of $1.5 \mathrm{ml}$ of the sample solutions with $1 \mathrm{ml}$ of $300 \mu \mathrm{M}$ NBT, $1 \mathrm{ml}$ of $468 \mu \mathrm{M}$ NADH, and $0.1 \mathrm{ml}$ of $60 \mu \mathrm{M}$ PMS were incubated for 5 minutes at $25^{\circ} \mathrm{C}$ and their absorbance was measured at $560 \mathrm{~nm}$ against the blank. In case of a blank, the sample was replaced by the PBS. Ascorbic acid was used as a positive control and the capability of the test sample for superoxide scavenging was determined by the following equation:

$\%$ Superoxide radical scavenging activity $=\left[\left(A_{0}-A_{1}\right) / A_{0}\right] \times 100$

where $A_{\mathrm{o}}$ is the control absorbance and $A_{1}$ is the test sample absorbance.

\subsection{Statistical Analysis}

All assays were carried out in triplicate and their outcomes were expressed as mean \pm standard deviation. The $\mathrm{IC}_{50}$ values (half maximal inhibitory concentration) of various extracts for different antioxidant assays were subjected to the statistical one-way analysis of variance (ANOVA) and the experimental results obtained were further analyzed by Tukey's post-hoc test. Mean values of outcomes were considered to be significant when $p<0.05$. Pearson's correlation analysis was carried to determine the correlation between the total phytochemical content and different antioxidant assays and their significance was determined at $p<0.05$. All statistical analysis was carried out using GraphPad Prism 8.0.2.

\section{RESULTS}

\subsection{Phytochemical Quantification}

The profile of total tannin, saponin, flavonoid, phenol, and flavonol in EN (Table 1) and their derived fractions were determined from standard curve of TA $\left(\mathrm{y}=0.1855 \mathrm{x}+0.1007 ; R^{2}=0.979\right)$, $\mathrm{QJ}\left(y=2.512 x+0.022 ; R^{2}=0.923\right), \mathrm{QR}(y=1.6041 x-0.0639$; $\left.R^{2}=0.990\right)$, RUT $\left(y=2.4862 x+0.3608 ; R^{2}=0.918\right)$, and GLA $\left(y=1.1251 x+0.2285 ; R^{2}=0.923\right)$, respectively.

\subsubsection{Total tannin content}

The results of the present assays indicated a wide range of significant variations in the content of tannin in the different parts of EN (Table 1 and Figure 1), ranged from 0.022-1.07 mg $\mathrm{TAq} / \mathrm{g}$ DM. The order of tannin content in different fractions of EN was as follows: leaf methanol (LME) > leaf chloroform $(\mathrm{LCH})>$ stem methanol $(\mathrm{SME})>$ stem chloroform $(\mathrm{SCH})>$ stem aqueous $(\mathrm{SAQ})>$ latex chloroform $(\mathrm{LXCH})>$ bark methanol $(\mathrm{BME})>$ bark aqueous $(\mathrm{BAQ})>$ stem ethyl acetate $(\mathrm{SEA})>$ leaf ethyl acetate $($ LEA) $>$ stem benzene $(\mathrm{SBE})>$ bark ethyl acetate $($ BEA $)>$ leaf petroleum ether $($ LPE $)>$ latex ethyl acetate $($ LXEA)
$>$ latex aqueous $(\mathrm{LXAQ})>$ leaf benzene $(\mathrm{LBE})>$ leaf aqueous $(\mathrm{LAQ})>$ stem petroleum ether $(\mathrm{SPE})>$ latex methanol $(\mathrm{LXME})$ $>$ bark petroleum ether $(\mathrm{BPE})>$ bark chloroform $(\mathrm{BCH})>$ latex benzene $(\mathrm{LXBE})>$ latex petroleum ether $(\mathrm{LXPE})>$ bark benzene (BBE). The methanolic extracts of leaf and stem contained higher tannin compounds $(p<0.05)$ than the other parts of EN with values of $1.07 \pm 0.0859$ and $0.992 \pm 0.105 \mathrm{mg}$ TAq $/ \mathrm{g} \mathrm{DM}$, respectively. Chloroform fraction in the case of latex $(0.781 \pm$ $0.107 \mathrm{mg} \mathrm{TAq} / \mathrm{g} \mathrm{DM})$ and the methanolic fraction in bark $(0.528$ $\pm 0.327 \mathrm{mg} \mathrm{TAq} / \mathrm{g} \mathrm{DM}$ ) showed a high level of tannin than the other solvent systems.

\subsubsection{Total saponin content}

The total saponin content of EN was determined by measuring the purple color generated by the reaction of saponin and acid. Generally, the total saponin content was found to be high in all plant parts with the stem showing the highest saponin content of 0.375 $\pm 0.0611 \mathrm{mg} \mathrm{QJq} / \mathrm{g} \mathrm{DM}$ in the methanol fraction, with $\mathrm{p}<0.05$. In the case of leaf, methanol fraction exhibited the highest saponin content $(0.331 \pm 0.211 \mathrm{mg} \mathrm{QJq} / \mathrm{g} \mathrm{DM})$, followed by benzene, petroleum ether, chloroform, ethyl acetate, and aqueous fractions. The results of EN latex and bark revealed the highest content in aqueous extract $(0.216 \pm 0.01 \mathrm{mg} \mathrm{QJq} / \mathrm{g} \mathrm{DM})$ and methanolic extract $(0.265 \pm 0.036 \mathrm{mg} \mathrm{QJq} / \mathrm{g} \mathrm{DM})$, respectively. The order of TSC of different fractions from different parts of EN was as follows: $\mathrm{SME}>\mathrm{SEA}>\mathrm{LME}>\mathrm{BME}>\mathrm{SAQ}>\mathrm{LXAQ}>\mathrm{SPE}>\mathrm{BAQ}>\mathrm{SCH}>$ $\mathrm{LBE}>\mathrm{LPE}>\mathrm{SBE}>\mathrm{LXPE}>\mathrm{LXEA}>\mathrm{BCH}>\mathrm{BEA}>\mathrm{LXBE}>\mathrm{LCH}>$ LEA $>$ LXCH $>$ LXME $>$ BPE $>$ BBE $>$ LAQ (Table 1 and Figure 2).

\subsubsection{Total flavonoid content}

The result analysis reported a significant variation in the flavonoid content (Table 1 and Figure 3). The order of TFC analysis from different EN parts was as follows: $\mathrm{SME}>\mathrm{LME}>\mathrm{SAQ}>\mathrm{SEA}>$ $\mathrm{LXEA}>\mathrm{LAQ}>\mathrm{BME}>\mathrm{BAQ}>\mathrm{SBE}>\mathrm{SCH}>\mathrm{LBE}>\mathrm{BEA}>\mathrm{BCH}>$ $\mathrm{BBE}>\mathrm{SPE}>\mathrm{LCH}>\mathrm{BPE}>\mathrm{LPE}>\mathrm{LXPE}>\mathrm{LEA}>\mathrm{LXCH}>\mathrm{LXBE}>$ LXAQ $>$ LXME. Among the studied EN parts, the highest flavonoid content was found in the methanolic extract of the stem with a value of $0.808 \pm 0.03 \mathrm{mg} Q \mathrm{Rq} / \mathrm{g} \mathrm{DM}$, followed by the methanolic fraction of leaf $(0.792 \pm 0.1 \mathrm{mg} Q R q / g$ DM $)$, ethyl acetate fraction of latex $(0.682 \pm 0.0173 \mathrm{mg} \mathrm{QRq} / \mathrm{g} \mathrm{DM})$, and methanolic fraction of bark $(0.561 \pm 0.0519 \mathrm{mg} \mathrm{QRq} / \mathrm{g} \mathrm{DM})$.

\subsubsection{Total phenol content}

There was a significant variation in the total phenolic present in different parts of EN ranging from 0.058 to $0.792 \mathrm{mg} \mathrm{GLAq} / \mathrm{g}$ DM of extract. Different fractions of EN possessed phenol in the following order: $\mathrm{SCH}>\mathrm{LME}>\mathrm{SME}>\mathrm{LAQ}>\mathrm{LXCH}>\mathrm{LCH}>\mathrm{SEA}>\mathrm{SAQ}>\mathrm{LBE}>$ $\mathrm{SPE}>\mathrm{SBE}>\mathrm{LEA}>\mathrm{BME}>\mathrm{LPE}>\mathrm{BAQ}>\mathrm{BEA}>\mathrm{BPE}>\mathrm{LXPE}>$ $\mathrm{LXBE}>\mathrm{BCH}>\mathrm{BBE}>\mathrm{LXEA}>\mathrm{LXME}>\mathrm{LXAQ}$. In case of leaf, the highest level of phenols was shown by methanol extract $(0.792 \pm$ $0.0953 \mathrm{mg} \mathrm{GLAq} / \mathrm{g}$ DM), followed by other extracts. Table 1 and Figure 4 summarized that the chloroform extract has shown the highest phenolic content in the case of both stem $(0.804 \pm 0.002$ $\mathrm{mg}$ GLAq/g DM) and latex (0.571 $\pm 0.0624 \mathrm{mg}$ GLAq/g DM), and methanolic extract in case of bark $(0.205 \pm 0.014 \mathrm{mg}$ GLAq $/ \mathrm{g}$ DM). 
Table 1: Total tannin, saponin, flavonoid, phenol, and flavonol content of EN leaf, stem, latex, and bark.

\begin{tabular}{|c|c|c|c|c|c|c|}
\hline Parts & Extracts & TTC (mg TAq/g DM) & $\begin{array}{c}\text { TSC (mg QJq/g } \\
\text { DM) }\end{array}$ & $\begin{array}{c}\text { TFC (mg QRq/g } \\
\text { DM) }\end{array}$ & $\begin{array}{c}\text { TPC (mg } \\
\text { GLAq/g DM) }\end{array}$ & TFLC (mg RUTq/g DM) \\
\hline \multirow[t]{6}{*}{ Leaf } & LPE & $0.235 \pm 0.0953^{\mathrm{cd}}$ & $0.177 \pm 0.1^{\mathrm{bc}}$ & $0.106 \pm 0.01^{\mathrm{de}}$ & $0.204 \pm 0.0953^{\mathrm{de}}$ & $0.0566 \pm 0.00519^{\mathrm{de}}$ \\
\hline & LBE & $0.208 \pm 0.0947^{\mathrm{d}}$ & $0.178 \pm 0.1^{\mathrm{ab}}$ & $0.359 \pm 0.0459^{c}$ & $0.485 \pm 0.0754^{\mathrm{c}}$ & $0.316 \pm 0.02^{\mathrm{b}}$ \\
\hline & $\mathrm{LCH}$ & $1.06 \pm 0.0721^{\mathrm{a}}$ & $0.159 \pm 0.1^{\mathrm{cd}}$ & $0.196 \pm 0.09^{\mathrm{cd}}$ & $0.561 \pm 0.0529^{\mathrm{bc}}$ & $0.283 \pm 0.0785^{\mathrm{c}}$ \\
\hline & LEA & $0.306 \pm 0.09^{\mathrm{b}}$ & $0.158 \pm 0.1^{\mathrm{de}}$ & $0.0415 \pm 0.01^{\mathrm{ef}}$ & $0.215 \pm 0.01^{\mathrm{d}}$ & $0.116 \pm 0.01^{\mathrm{d}}$ \\
\hline & LME & $1.07 \pm 0.0859^{\mathrm{a}}$ & $0.331 \pm 0.2116^{\mathrm{a}}$ & $0.792 \pm 0.1^{\mathrm{a}}$ & $0.792 \pm 0.0953^{\mathrm{a}}$ & $0.577 \pm 0.0721^{\mathrm{a}}$ \\
\hline & LAQ & $0.194 \pm 0.004^{\mathrm{e}}$ & $\begin{array}{l}0.0212 \pm \\
0.0382^{\mathrm{ef}}\end{array}$ & $0.612 \pm 0.0754^{\mathrm{b}}$ & $0.602 \pm 0.0049^{\mathrm{b}}$ & $0.306 \pm 0.01^{\mathrm{bc}}$ \\
\hline \multirow[t]{6}{*}{ Stem } & SPE & $0.128 \pm 0.03005^{\mathrm{e}}$ & $0.209 \pm 0.0095^{\mathrm{cd}}$ & $0.265 \pm 0.0519^{\mathrm{d}}$ & $0.292 \pm 0.002^{\mathrm{d}}$ & $0.038 \pm 0.02^{\mathrm{e}}$ \\
\hline & SBE & $0.3 \pm 0.0877^{\mathrm{cd}}$ & $0.177 \pm 0.0624^{\mathrm{ef}}$ & $0.394 \pm 0.09^{c}$ & $0.272 \pm 0.007^{\mathrm{d}}$ & $0.324 \pm 0.02^{\mathrm{cd}}$ \\
\hline & $\mathrm{SCH}$ & $0.848 \pm 0.0998^{\mathrm{ab}}$ & $0.192 \pm 0.0655^{\mathrm{de}}$ & $0.381 \pm 0.08^{\mathrm{cd}}$ & $0.804 \pm 0.002^{\mathrm{a}}$ & $0.288 \pm 0.0984^{\mathrm{d}}$ \\
\hline & SEA & $0.365 \pm 0.0921^{\mathrm{c}}$ & $0.369 \pm 0.0328^{\mathrm{ab}}$ & $0.707 \pm 0.01^{b}$ & $0.547 \pm 0.0556^{\mathrm{bc}}$ & $0.377 \pm 0.0346^{\mathrm{ab}}$ \\
\hline & SME & $0.992 \pm 0.1055^{\mathrm{a}}$ & $0.375 \pm 0.0611^{\mathrm{a}}$ & $0.808 \pm 0.03^{\mathrm{a}}$ & $0.624 \pm 0.0888^{b}$ & $0.41 \pm 0.06^{\mathrm{a}}$ \\
\hline & SAQ & $0.812 \pm 0.0091^{\mathrm{d}}$ & $0.261 \pm 0.1068^{\mathrm{bc}}$ & $0.708 \pm 0.05^{\mathrm{ab}}$ & $0.528 \pm 0.02^{\mathrm{c}}$ & $0.345 \pm 0.03^{\mathrm{bc}}$ \\
\hline \multirow[t]{6}{*}{ Latex } & LXPE & $0.024 \pm 0.02^{\mathrm{f}}$ & $0.169 \pm 0.0264^{b c}$ & $0.017 \pm 0.01^{\mathrm{e}}$ & $0.051 \pm 0.04^{\mathrm{f}}$ & $0.0231 \pm 0.0030^{\mathrm{f}}$ \\
\hline & LXBE & $0.025 \pm 0.0021^{\mathrm{ef}}$ & $0.161 \pm 0.0655^{\mathrm{cd}}$ & $0.0567 \pm 0.0088^{\mathrm{cd}}$ & $0.165 \pm 0.0519^{\mathrm{b}}$ & $0.214 \pm 0.0081^{\mathrm{b}}$ \\
\hline & $\mathrm{LXCH}$ & $0.781 \pm 0.1070^{\mathrm{a}}$ & $0.15 \pm 0.0573^{\mathrm{de}}$ & $0.046 \pm 0.0079^{\mathrm{d}}$ & $0.571 \pm 0.0624^{\mathrm{a}}$ & $0.181 \pm 0.0748^{\mathrm{bc}}$ \\
\hline & LXEA & $0.229 \pm 0.1^{\mathrm{bc}}$ & $0.169 \pm 0.06^{\mathrm{ab}}$ & $0.682 \pm 0.0173^{\mathrm{a}}$ & $0.099 \pm 0.05^{\mathrm{de}}$ & $0.137 \pm 0.0244^{\mathrm{cd}}$ \\
\hline & LXME & $0.128 \pm 0.03^{\mathrm{de}}$ & $0.085 \pm 0.01^{\text {ef }}$ & $0.099 \pm 0.01^{\mathrm{b}}$ & $0.099 \pm 0.07^{\mathrm{cd}}$ & $0.0406 \pm 0.00021^{\mathrm{ef}}$ \\
\hline & LXAQ & $0.211 \pm 0.0916^{\mathrm{cd}}$ & $0.216 \pm 0.01^{\mathrm{a}}$ & $\begin{array}{l}0.0803 \pm \\
0.00057^{\mathrm{bc}}\end{array}$ & $0.058 \pm 0.01^{\mathrm{ef}}$ & $0.351 \pm 0.0326^{\mathrm{a}}$ \\
\hline \multirow[t]{6}{*}{ Bark } & $\mathrm{BPE}$ & $0.057 \pm 0.0295^{\mathrm{de}}$ & $0.0463 \pm 0.0089^{\mathrm{d}}$ & $0.169 \pm 0.522^{\mathrm{e}}$ & $0.186 \pm 0.01^{\mathrm{cd}}$ & $0.167 \pm 0.0519^{\text {ef }}$ \\
\hline & $\mathrm{BBE}$ & $0.022 \pm 0.02^{\mathrm{f}}$ & $0.025 \pm 0.0072^{\mathrm{de}}$ & $0.287 \pm 0.01^{\mathrm{d}}$ & $0.123 \pm 0.02^{\mathrm{ef}}$ & $0.258 \pm 0.0458^{\mathrm{a}}$ \\
\hline & $\mathrm{BCH}$ & $0.047 \pm 0.0175^{\mathrm{ef}}$ & $0.165 \pm 0.06^{\mathrm{bc}}$ & $0.303 \pm 0.01^{\mathrm{cd}}$ & $0.126 \pm 0.019^{\mathrm{de}}$ & $0.172 \pm 0.0624^{\mathrm{de}}$ \\
\hline & BEA & $0.292 \pm 0.1^{\mathrm{bc}}$ & $0.164 \pm 0.0435^{\mathrm{c}}$ & $0.342 \pm 0.04^{c}$ & $0.196 \pm 0.09^{\mathrm{bc}}$ & $0.187 \pm 0.0754^{\mathrm{bc}}$ \\
\hline & BME & $0.528 \pm 0.327^{\mathrm{a}}$ & $0.265 \pm 0.0360^{\mathrm{a}}$ & $0.561 \pm 0.0519^{\mathrm{a}}$ & $0.205 \pm 0.014^{\mathrm{a}}$ & $0.198 \pm 0.02^{\mathrm{ab}}$ \\
\hline & BAQ & $0.408 \pm 0.0879^{\mathrm{ab}}$ & $0.193 \pm 0.0285^{\mathrm{a}}$ & $0.459 \pm 0.0360^{\mathrm{b}}$ & $0.199 \pm 0.0095^{\mathrm{ab}}$ & $0.178 \pm 0.02^{\mathrm{cd}}$ \\
\hline \multirow[t]{5}{*}{ Standards } & Tannic acid & $0.239 \pm 0.00058^{\mathrm{f}, \mathrm{g}}$ & - & - & - & - \\
\hline & Quillaja & - & $0.019 \pm 0.001^{\mathrm{fe}}$ & - & - & - \\
\hline & Quercetin & - & - & $0.0062 \pm 0.0011^{\mathrm{fe}}$ & - & - \\
\hline & Gallic acid & - & - & - & $0.106 \pm 0.003^{\mathrm{fe}, \mathrm{g}}$ & - \\
\hline & Rutin & - & - & - & - & $0.0512 \pm 0.0011^{\mathrm{fgg}}$ \\
\hline
\end{tabular}

The values represent the means of three measurements \pm standard deviation. Values in the same column with the different superscript letters are significantly different at $p<0.05$. TA: tannic acid, QJ: quillaja, QR: quercetin, GLA: gallic acid, RUT: rutin, DM: dry matter, LPE: leaf petroleum ether, LBE: leaf benzene, LCH: leaf chloroform, LEA: leaf ethyl acetate, LME: leaf methanol, LAQ: leaf aqueous, SPE: stem petroleum ether, SBE: stem benzene, SCH: stem chloroform, SEA: stem ethyl acetate, SME: stem methanol, SAQ: stem aqueous, LXPE: latex petroleum ether, LXBE: latex benzene, LXCH: latex chloroform, LXEA: latex ethyl acetate, LXME: latex methanol, LXAQ: latex aqueous, BPE: bark petroleum ether, BBE: bark benzene, $\mathrm{BCH}$ : bark chloroform, BEA: bark ethyl acetate, BME: bark methanol, BAQ: bark aqueous.

\subsubsection{Total flavonol content}

The TFLC of all the four parts of EN was significant at $p<0.05$ (Table 1 and Figure 5). Flavonol analysis revealed that their content ranged from 0.023 to $0.577 \mathrm{mg}$ RUTq/g DM, respectively. Methanolic fraction of leaf contained a higher content of flavonol, followed by benzene, aqueous, chloroform, ethyl acetate, and petroleum ether fraction. However, in case of stem, methanol fraction showed the highest content of flavonol $(0.41 \pm 0.06$ RUTq/g DM), followed by ethyl acetate, aqueous, benzene, chloroform, and petroleum ether fraction, respectively.

EN latex had the highest amount of flavonols in aqueous fraction $(0.351 \pm 0.0326 \mathrm{mg} \mathrm{RUTq} / \mathrm{g} \mathrm{DM})$, followed by benzene, chloroform, ethyl acetate, methanol, and petroleum ether fraction, respectively. The results obtained from bark revealed a high level of flavonol in the benzene extract $(0.258 \pm 0.0458 \mathrm{mg} \mathrm{RUTq} / \mathrm{g}$ $\mathrm{DM})$, followed by other fractions, respectively.

\subsection{Antioxidant Activity}

\subsubsection{Hydrogen peroxide scavenging assay}

The ability of various EN fractions to scavenge $\mathrm{H}_{2} \mathrm{O}_{2}$ is presented in Table 2 and Figure 6 using ascorbic acid as the standard The scavenging activity for hydrogen peroxide of various extracts from $\mathrm{EN}$ was in the following order: LME $>$ ascorbic acid $>$ BAQ $>$ S BE $>$ S ME $>$ LAQ $>$ SEA $>$ SAQ $>$ SCH $>$ SPE $>$ 


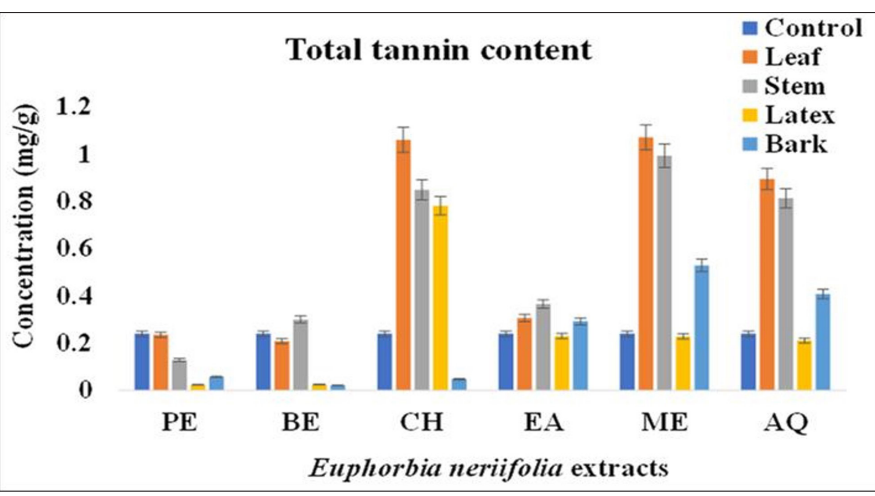

Figure 1: Total tannin content of different parts of E. neriifolia. PE: Petroleum ether, BE: Benzene, CH: Chloroform, EA: Ethyl acetate, ME: Methanol, AQ: Aqueous.

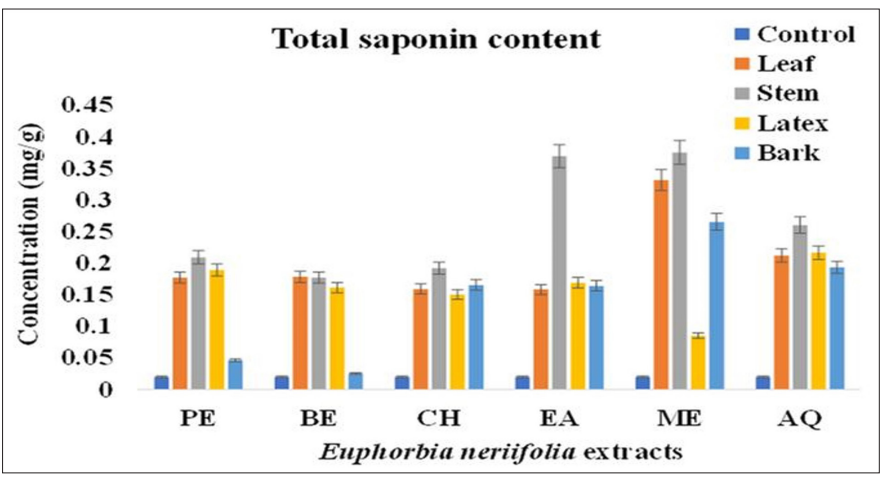

Figure 2: Total saponin content of different parts of E. neriifolia. PE: Petroleum ether, BE: Benzene, CH: Chloroform, EA: Ethyl acetate, ME: Methanol, AQ: Aqueous.

$\mathrm{LEA}>\mathrm{BEA}>\mathrm{LPE}>\mathrm{BBE}>\mathrm{BME}>\mathrm{LXME}>\mathrm{LXAQ}>\mathrm{BCH}>\mathrm{LXEA}>$ $\mathrm{LCH}>\mathrm{LXCH}>\mathrm{BPE}>\mathrm{LXBE}>\mathrm{LXPE}>\mathrm{LBE}$. The methanol extracts of the leaf $(2.06 \pm 0.034 \mu \mathrm{g} / \mathrm{ml})$ and stem $(2.9 \pm 0.0635 \mu \mathrm{g} / \mathrm{ml})$ showed better $\mathrm{H}_{2} \mathrm{O}_{2}$ scavenging activity than the other solvent systems. Similarly, the aqueous extract of bark $(2.2 \pm 0.0401$ $\mu \mathrm{g} / \mathrm{ml})$ and the methanolic extract of latex $(6.8 \pm 0.0692 \mu \mathrm{g} /$ $\mathrm{ml}$ ) had more pronounced scavenging activity. Furthermore, the antioxidant activity of methanol extract of leaf and aqueous extract of bark was higher or equal than that of ascorbic acid, which was determined by their low value of $\mathrm{IC}_{50}$.

\subsubsection{FRAP assay}

The FRAP was determined by the ferric-reducing ability of the standard and the plant extracts as summarized in Table 2. It was recorded that an increase in absorbance of the test samples is an indication of a rise in reducing power. In this work, the reducing power of EN and the standard was correlated with their concentrations and it was in the following order: $\mathrm{BHT}>\mathrm{LME}>$ $\mathrm{BCH}>\mathrm{BPE}>\mathrm{BBE}>\mathrm{LXBE}>\mathrm{LXAQ}>\mathrm{LXCH}>\mathrm{SAQ}>\mathrm{LCH}>\mathrm{LPE}>$ $\mathrm{LAQ}>\mathrm{LXEA}>\mathrm{BME}>\mathrm{BAQ}>\mathrm{BEA}>\mathrm{LEA}>\mathrm{SME}>\mathrm{SPE}>$ $\mathrm{SBE}>\mathrm{LXPE}>\mathrm{LBE}>\mathrm{SEA}>\mathrm{SCH}>\mathrm{LXME}$. The methanolic extract of leaf $(153 \pm 79.67 \mu \mathrm{M} \mathrm{Fe}(\mathrm{II}) / \mathrm{g})$ and aqueous extract of the stem $(288.2 \pm 5.77 \mu \mathrm{M} \mathrm{Fe}(\mathrm{II}) / \mathrm{g})$ showed better antioxidant activity than the other solvent systems. The FRAP activity of the plant extracts was less than the standard but was significant $(p<0.05)$. As shown

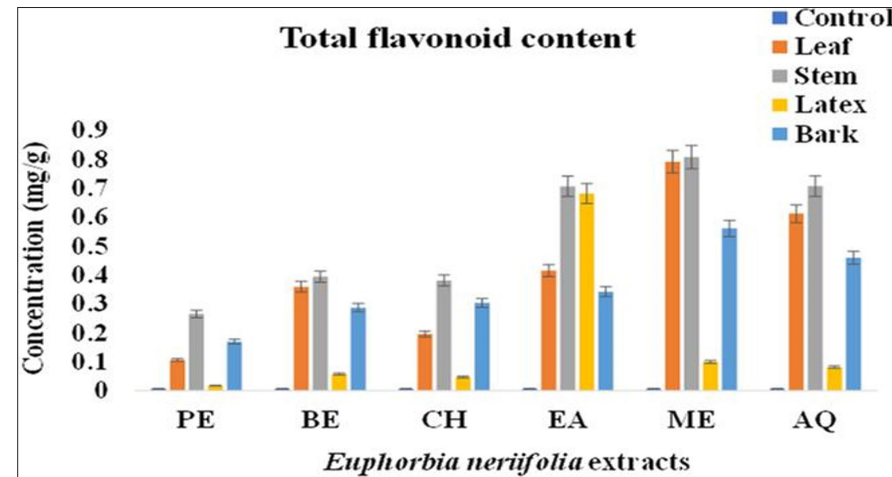

Figure 3: Total flavonoid content of different parts of E. neriifolia. PE: Petroleum ether, BE: Benzene, $\mathrm{CH}$ : Chloroform, EA: Ethyl acetate, ME: Methanol, AQ: Aqueous.

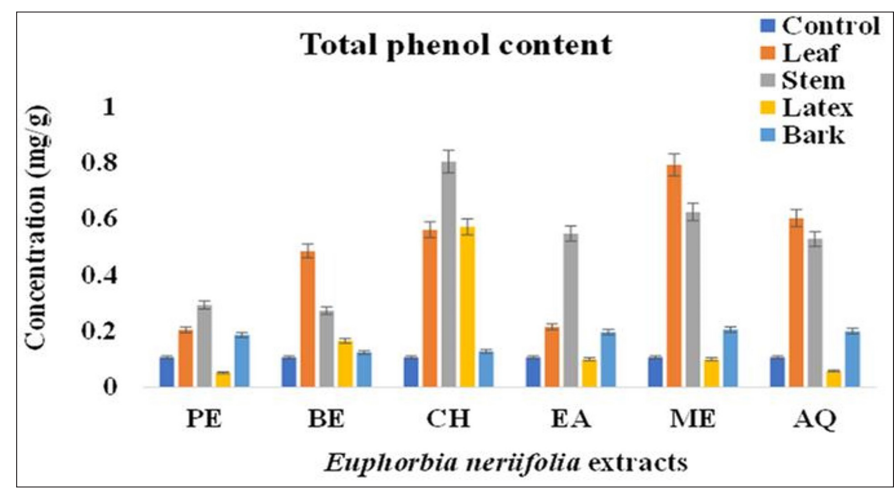

Figure 4: Total phenol content of different parts of E. neriifolia. PE: Petroleum ether, BE: Benzene, CH: Chloroform, EA: Ethyl acetate, ME: Methanol, AQ: Aqueous .

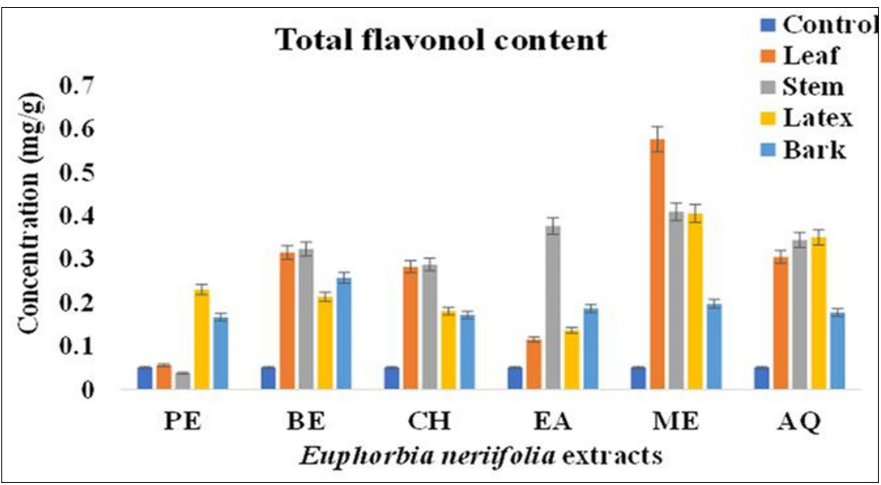

Figure 5: Total flavonol content of different parts of E. neriifolia. PE: Petroleum ether, BE: Benzene, $\mathrm{CH}$ : Chloroform, EA: Ethyl acetate, ME: Methanol, AQ: Aqueous.

in Figure 7, the benzene extract of leaf, ethyl acetate extract of the stem, and methanol extract of latex exhibited poor ferric ionreducing power.

\subsubsection{DPPH scavenging activity}

The antioxidant activity of all extracts of EN was assessed by the free radical DPPH reduction method along with the known synthetic standard, viz. ascorbic acid. The results obtained are 
Euphorbia neriifolia Linn 2022;10(02):133-145

Table 2: $\mathrm{IC}_{50}$ of different extracts of E. neriifolia leaf, stem, latex, and bark for various antioxidant systems.

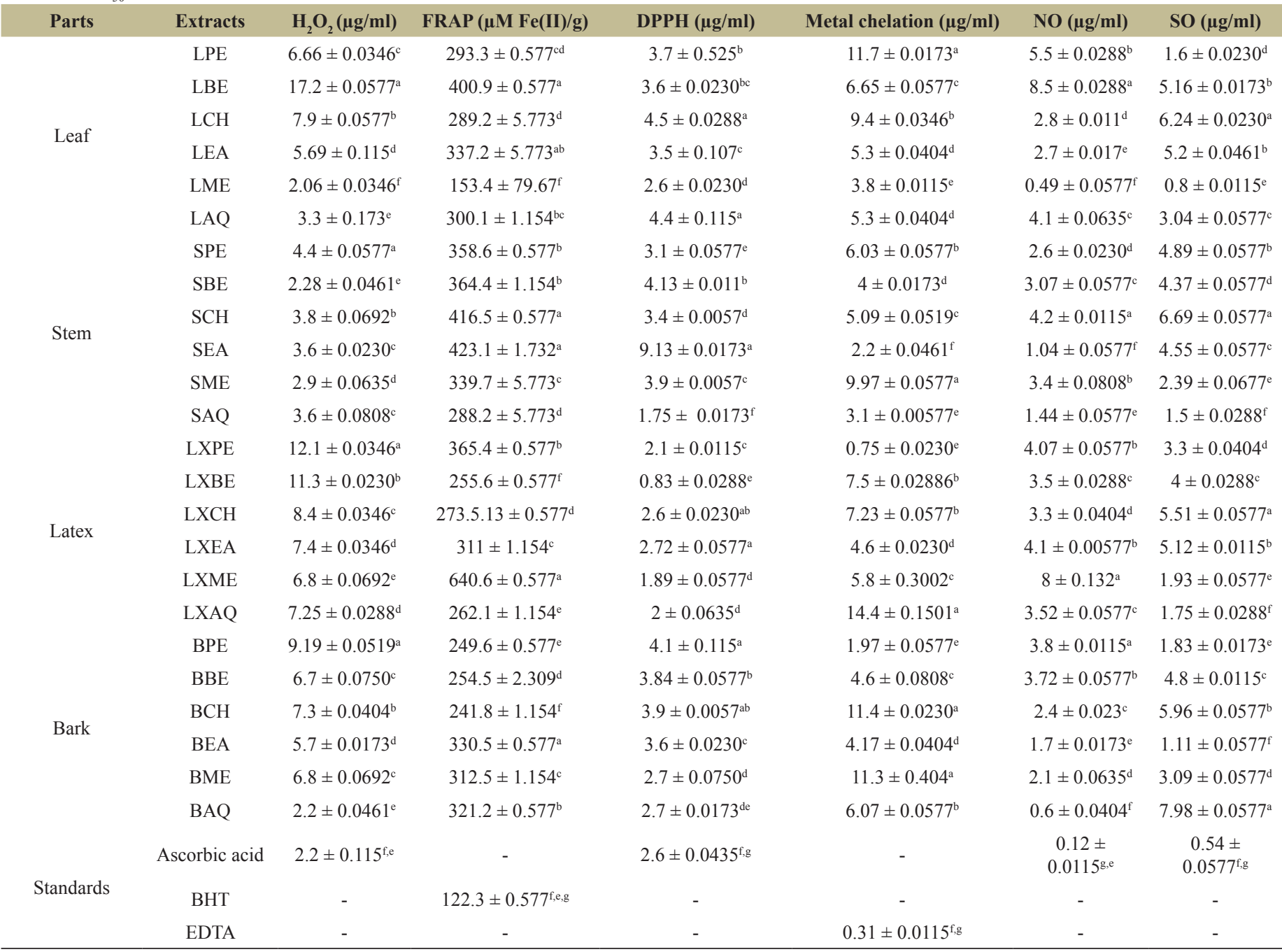

The values represent the means of three measurements \pm standard deviation. Values in the same column with the different superscript letters are significantly different at $p<0.05$.

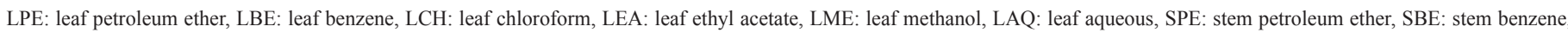

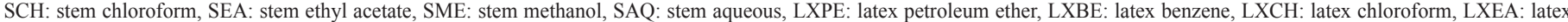

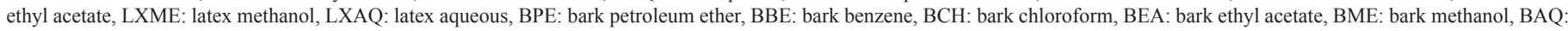
bark aqueous.

presented in Table 2 and Figure 8. The $\mathrm{IC}_{50}$ values of DPPH radical of the test samples were in the following order: $\mathrm{LXBE}>\mathrm{SAQ}>$ $\mathrm{LXME}>\mathrm{LXAQ}>\mathrm{LXPE}>$ ascorbic acid $>\mathrm{LME}>\mathrm{LXCH}>\mathrm{BME}>$ $\mathrm{BAQ}>\mathrm{LXEA}>\mathrm{SPE}>\mathrm{SCH}>\mathrm{LEA}>\mathrm{LBE}>\mathrm{BEA}>\mathrm{LPE}>\mathrm{BBE}>$ $\mathrm{BCH}>\mathrm{SME}>\mathrm{BPE}>\mathrm{SBE}>\mathrm{LAQ}>\mathrm{LCH}>\mathrm{SEA}$. A lower $\mathrm{IC}_{50}$ value denoted a higher antioxidant activity. Among all extracts, the benzene extract of latex $(0.83 \pm 0.0288 \mu \mathrm{g} / \mathrm{ml})$ represented the lowest $\mathrm{IC}_{50}$ value. Similarly, the methanolic and aqueous extract of leaf, stem, and bark also exhibited better scavenging activity. Furthermore, the $\mathrm{IC}_{50}$ values of latex benzene, stem aqueous, latex methanol, latex aqueous, and latex petroleum ether extracts were lower than that of ascorbic acid, which suggested the higher antioxidant activity of these extracts than that of ascorbic acid.

\subsubsection{Metal chelation assay}

Here, we screened the iron-chelating ability of different parts of EN. All extracts showed an ability to chelate metals ions as listed in Table 2 and shown in Figure 9. The $\mathrm{IC}_{50}$ of the

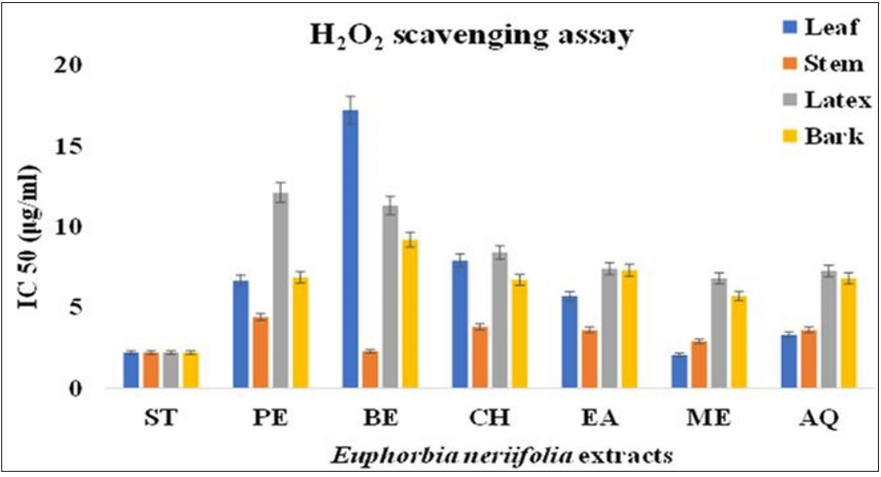

Figure 6: $\mathrm{IC}_{50}$ values of different parts of $E$. neriifolia for hydrogen peroxide scavenging. PE: Petroleum ether, BE: Benzene, $\mathrm{CH}$ : Chloroform, EA: Ethyl acetate, ME: Methanol, AQ: Aqueous.

EN extracts for chelating iron was in the following order: EDTA $>$ LXPE $>$ BPE $>$ SEA $>$ SAQ $>$ LME $>$ SBE $>$ BEA $>$ LXEA $>$ 
$\mathrm{BBE}>\mathrm{SCH}>\mathrm{LEA}>\mathrm{LAQ}>\mathrm{LXME}>\mathrm{SPE}>\mathrm{BAQ}>\mathrm{LBE}>\mathrm{LXCH}>$ $\mathrm{LXBE}>\mathrm{LCH}>\mathrm{SME}>\mathrm{BME}>\mathrm{BCH}>\mathrm{LPE}>\mathrm{LXAQ}$. The results of the chelating iron indicated that the petroleum ether fraction of latex $(0.75 \pm 0.0230 \mu \mathrm{g} / \mathrm{ml})$, followed by ethyl acetate fraction of stem $(2.2 \pm 0.0461 \mu \mathrm{g} / \mathrm{ml})$, a methanolic fraction of leaf $(3.8 \pm 0.0115$ $\mu \mathrm{g} / \mathrm{ml})$, and ethyl acetate fraction of bark $(4.17 \pm 0.0404 \mu \mathrm{g} / \mathrm{ml})$, had the largest and significant ability $(p<0.05)$ to chelate iron, while the aqueous extract of latex showed the lowest ability with an $\mathrm{IC}_{50}$ value of $14.4 \pm 0.01501 \mu \mathrm{g} / \mathrm{ml}$.

\subsubsection{Nitric oxide radical scavenging assay}

NO scavenging ability of the EN samples was in the following order: Ascorbic acid $>$ LME $>$ BAQ $>$ SEA $>$ SAQ $>$ BEA $>$ BME $>$ $\mathrm{BCH}>\mathrm{SPE}>\mathrm{LEA}>\mathrm{LCH}>\mathrm{SBE}>\mathrm{LXCH}>\mathrm{SME}>\mathrm{LXBE}>\mathrm{LXAQ}>$ $\mathrm{BBE}>\mathrm{BPE}>\mathrm{LXPE}>\mathrm{LXEA}>\mathrm{LAQ}>\mathrm{SCH}>\mathrm{LPE}>\mathrm{LXME}>\mathrm{LBE}$. The methanolic extract of the leaf had the lowest $\mathrm{IC}_{50}$ value $(0.49 \pm$ $0.0577 \mu \mathrm{g} / \mathrm{ml}$ ), followed by other extracts, which is an indication of strong NO scavenging activity with minimum concentration to achieve $50 \%$ radical scavenging. However, the $\mathrm{IC}_{50}$ value of EN samples was higher than that of ascorbic acid $(0.12 \pm 0.0115 \mu \mathrm{g} /$ $\mathrm{ml}$ ), which indicates the lower scavenging activity of extracts in comparison to the standard as summarized in Table 2 and Figure 10.

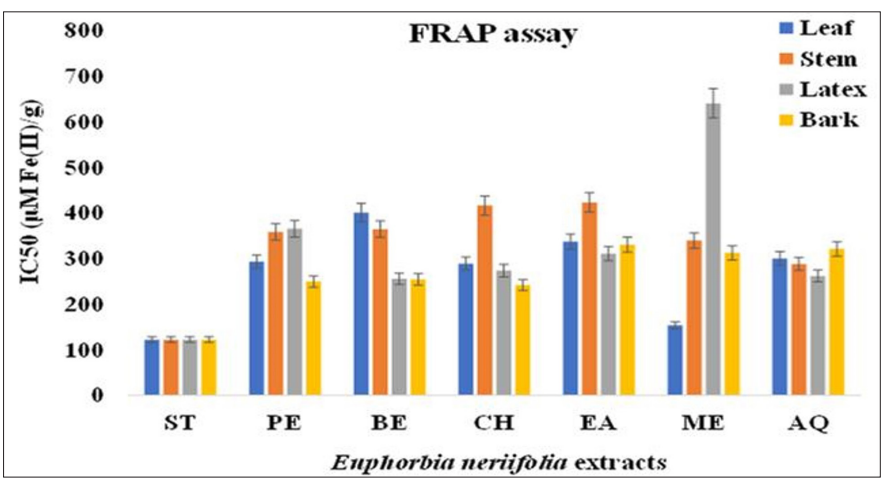

Figure 7: $\mathrm{IC}_{50}$ value of different parts of $E$. neriifolia for reducing ferric ions. PE: Petroleum ether, BE: Benzene, CH: Chloroform, EA: Ethyl acetate, ME: Methanol, AQ: Aqueous.

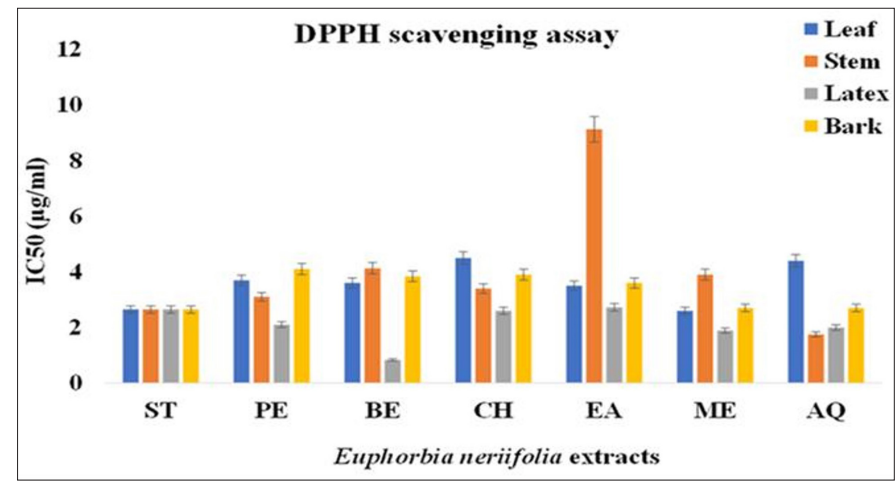

Figure 8: $\mathrm{IC}_{50}$ value of different parts of E. neriifolia for scavenging DPPH. PE: Petroleum ether, BE: Benzene, CH: Chloroform, EA: Ethyl acetate, ME: Methanol, AQ: Aqueous.

\subsubsection{Superoxide radical scavenging assay}

Figure 11 shows the abilities of leaf, stem, latex, and bark extracts and the reference compound (ascorbic acid) to quench the superoxide radicals in the PMS-NADH reaction mixture. The $\mathrm{IC}_{50}$ of the extracts was in the order: ascorbic acid $>$ LME $>$ BEA $>$ SAQ $>$ LPE $>$ LXAQ $>$ BPE $>$ LXME $>$ SME $>$ $\mathrm{LAQ}>\mathrm{BME}>\mathrm{LXPE}>\mathrm{LXBE}>\mathrm{SBE}>\mathrm{SEA}>\mathrm{BBE}>\mathrm{SPE}>\mathrm{LXEA}>$ $\mathrm{LBE}>\mathrm{LEA}>\mathrm{LXCH}>\mathrm{BCH}>\mathrm{LCH}>\mathrm{SCH}>\mathrm{BAQ}$. The antioxidant activity of methanolic extract of the leaf $(0.8 \pm 0.0115 \mu \mathrm{g} / \mathrm{ml})$ was highest when compared to extracts of the stem, latex, and bark parts of EN. Superoxide scavenging activity of extracts was lower than the standard but was found to be significant $(p<0.05)$.

The activity difference obtained from leaf, stem, latex, and bark samples might be due to the phytochemical constituents, extraction procedures, and samples processing. The methanolic extract of the leaf showed better activity in comparison to others.

\section{CORRELATION WITH PHYTOCHEMICAL CONTENTS AND ANTIOXIDANT ACTIVITY}

The antioxidant activity of plants might be due to the presence of phytochemicals. Hence, we assessed the coefficients of determination $\left(R^{2}\right)$ between the antioxidant potential and the

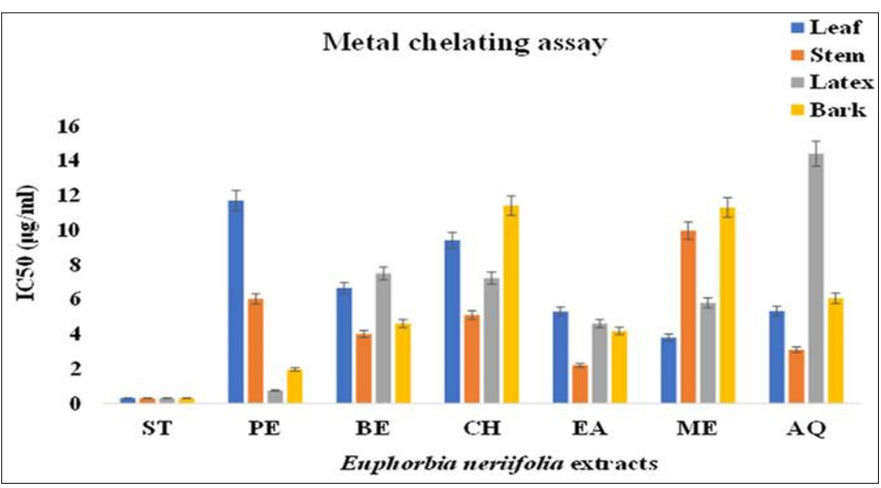

Figure 9: $\mathrm{IC}_{50}$ values of different parts of for chelating metal ions. PE: Petroleum ether, BE: Benzene, $\mathrm{CH}$ : Chloroform, EA: Ethyl acetate, ME: Methanol, AQ: Aqueous.

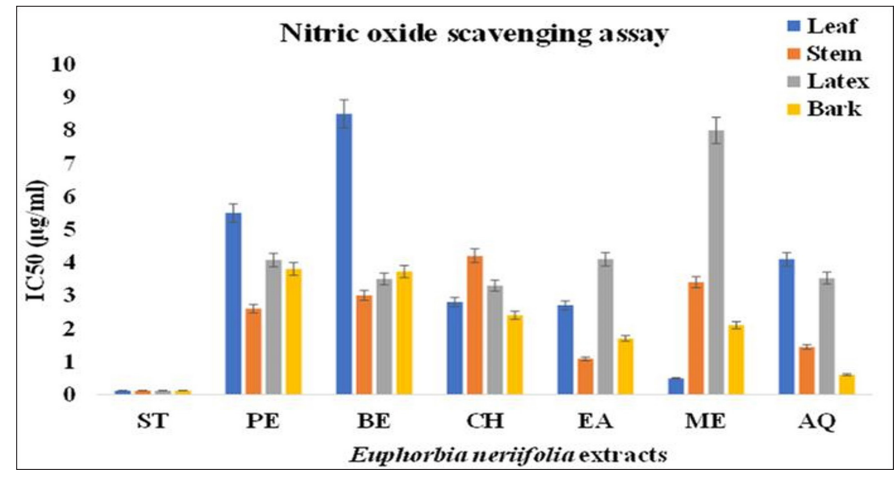

Figure 10: $\mathrm{IC}_{50}$ values of different extract of $E$. neriifolia for nitric oxide scavenging. PE: Petroleum ether, BE: Benzene, $\mathrm{CH}$ : Chloroform, EA: Ethyl acetate, ME: Methanol, AQ: Aqueous. 
phytochemical content of different parts of EN, as shown in Table 3. It should be noted that the correlations between tannin, saponin, flavonoid, phenol, and flavonols and antioxidant activity assayed by $\mathrm{H}_{2} \mathrm{O}_{2}$, FRAP, DPPH, metal chelating, $\mathrm{NO}$, and $\mathrm{SO}$ varied with different parts of EN analyzed.

The results determined that correlation between TFC and $\mathrm{H}_{2} \mathrm{O}_{2}$ was strong and significant for leaf $\left(R^{2}=0.892 *\right)(p<0.05)$, while weak for TTC and FRAP $\left(R^{2}=0.120\right)$, TTC and NO $\left(R^{2}=0.210\right)$, TFC and DPPH $\left(R^{2}=0.180\right)$, and TFLC and DPPH $\left(R^{2}=0.111\right)$.

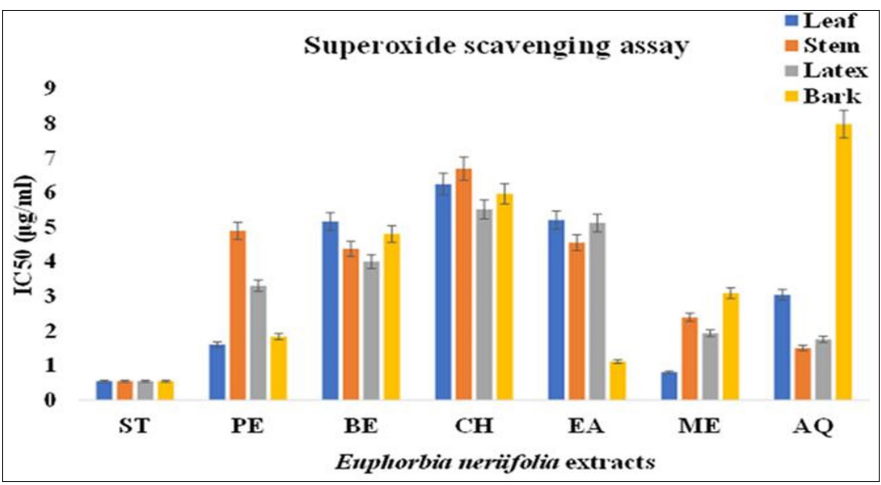

Figure 11: $\mathrm{IC}_{50}$ value of different extract $E$. neriifolia for super oxide scavenging. PE: Petroleum ether, BE: Benzene, $\mathrm{CH}$ : Chloroform, EA: Ethyl acetate, ME: Methanol, AQ: Aqueous.
The content of tannin, saponin, flavonoid, and flavonol showed a moderate correlation with FRAP, DPPH, metal and NO, while a weak correlation with $\mathrm{SO}$ in the case of stem.

A strong and significant correlation was found between TSC and SO for latex $\left(R^{2}=0.711\right)(p<0.05)$, while moderate for TFC and SO $\left(R^{2}=0.659^{*}\right)(p<0.05)$ and TFLC and SO $\left(R^{2}=0.528\right)$, and weak for TTC and DPPH $\left(R^{2}=0.307\right)$, TTC and SO $\left(R^{2}=0.220\right)$, and TPC and SO $\left(R^{2}=0.301\right)$

There was a significant and strong correlation between the antioxidant activity determined by DPPH $\left(R^{2}=0.718^{*}\right)(p<0.05)$, $\mathrm{H}_{2} \mathrm{O}_{2}\left(R^{2}=0.701^{*}\right)(p<0.05)$, and total flavonol content in case of bark. A non-significant moderate correlation was reported between TTC and metal chelation, TTC and SO, TSC and DPPH, TFC and $\mathrm{H}_{2} \mathrm{O}_{2}$, TFC and $\mathrm{NO}$, and a significant moderate correlation was reported between TFLC and SO $\left(R^{2}=0.665^{*}\right)(p<0.05)$. TSC and metal chelation, TSC and NO, TFC and FRAP, TFC and DPPH, TFC and Metal chelation, TPC and DPPH, TPC and Metal chelation, and TPC and NO showed the weak correlation in the case of bark.

\section{DISCUSSION}

Medicinal plants are the major sources of phytochemicals which play an important role in various biological activities [35]. The functional properties of a plant are based upon the types of secondary metabolites it possesses such as phenolics, terpenoids,

Table 3: Pearson's correlation $\left(R^{2}\right.$ values) between the $\mathrm{IC}_{50}$ values of antioxidant activities and phytochemical content of leaf, stem, latex, and bark of E. neriifolia.

\begin{tabular}{|c|c|c|c|c|c|c|}
\hline Parts & Samples & TTC & TSC & TFC & TPC & TFLC \\
\hline \multirow[t]{6}{*}{ Leaf } & $\mathrm{H}_{2} \mathrm{O}_{2}$ & 0.043 & 0.020 & $0.892 *$ & 0.037 & 0.020 \\
\hline & FRAP & 0.120 & 0.0001 & 0.051 & 0.009 & 0.026 \\
\hline & DPPH & 0.001 & 0.098 & 0.180 & 0.035 & 0.111 \\
\hline & Metal chelation & 0.007 & 0.070 & 0.004 & 0.0001 & 0.036 \\
\hline & NO & 0.210 & 0.0002 & 0.009 & 0.011 & 0.025 \\
\hline & $\mathrm{SO}$ & 0.009 & 0.024 & 0.036 & 0.029 & 0.0004 \\
\hline \multirow[t]{6}{*}{ Stem } & $\mathrm{H}_{2} \mathrm{O}_{2}$ & 0.027 & 0.051 & 0.004 & 0.016 & 0.021 \\
\hline & FRAP & 0.117 & 0.488 & 0.440 & 0.384 & 0.398 \\
\hline & DPPH & 0.005 & 0.540 & 0.466 & 0.180 & $0.589 *$ \\
\hline & Metal chelation & 0.443 & 0.335 & 0.373 & 0.184 & 0.104 \\
\hline & NO & 0.432 & 0.155 & 0.191 & 0.376 & 0.123 \\
\hline & SO & 0.063 & 0.209 & 0.139 & 0.311 & 0.157 \\
\hline \multirow[t]{6}{*}{ Latex } & $\mathrm{H}_{2} \mathrm{O}_{2}$ & 0.049 & $0.615^{*}$ & 0.036 & 0.002 & 0.094 \\
\hline & FRAP & 0.038 & 0.007 & 0.009 & 0.033 & 0.069 \\
\hline & $\mathrm{DPPH}$ & 0.307 & 0.013 & 0.054 & 0.042 & 0.095 \\
\hline & Metal chelation & 0.002 & 0.038 & 0.089 & 0.068 & 0.053 \\
\hline & NO & 0.037 & 0.0001 & 0.0004 & 0.015 & 0.011 \\
\hline & $\mathrm{SO}$ & 0.220 & $0.711^{*}$ & $0.659^{*}$ & 0.301 & 0.528 \\
\hline \multirow[t]{6}{*}{ Bark } & $\mathrm{H}_{2} \mathrm{O}_{2}$ & 0.099 & 0.389 & 0.540 & 0.044 & $0.701 *$ \\
\hline & FRAP & 0.057 & 0.084 & 0.139 & 0.031 & 0.066 \\
\hline & DPPH & 0.070 & 0.407 & 0.240 & 0.372 & $0.718^{*}$ \\
\hline & Metal chelation & 0.428 & 0.131 & 0.145 & 0.218 & 0.003 \\
\hline & NO & 0.0024 & 0.207 & 0.472 & 0.228 & $0.665^{*}$ \\
\hline & SO & 0.614 & 0.0066 & 0.008 & 0.0036 & 0.003 \\
\hline
\end{tabular}

*Correlation is significant at the 0.05 level (2-tailed). 
saponin, alkaloids, etc. These metabolites in plants greatly determine the antioxidant, antimicrobial, anti-inflammatory, and many other properties [36]. These properties are primarily due to their redox activities, which are important in adsorbing and scavenging the free radicals. It is, therefore, justifiable to evaluate the phytochemical content in the plants [37].

Among the phytochemicals, tannin was recorded in higher amounts in the methanolic extract of EN leaf. The most effective bioactive compounds, flavonoid, and phenol were found in polar methanolic and chloroform extracts of EN stem. Saponin and flavonols were also recorded in appreciable levels in the methanolic extract of the EN stem and leaves. Tannins are phenolic compounds that possess antibacterial and antioxidant properties and also have the ability to generate complexes with metal ions and macromolecules [38]. In the present study, the content of tannin was higher than that reported by Pracheta et al. [39] for EN, i.e., $0.98 \pm 0.06 \mathrm{mg} / \mathrm{g}$. Quantitative analysis revealed $5.14 \%$ of tannin content in case of Jatropha gossypifolia L. [40], whereas $18.5 \%$ of tannin content was reported from Euphorbia dracunculoides L. by Khattak et al. [41]. In a study of 53 species, the tannin content of $0.7 \mathrm{mg} / \mathrm{ml} \mathrm{Gallic}$ acid equivalent was reported from the acetone extract of leaf in the family Euphorbiaceae [42]. Labu et al. [43] reported the 241.41 $\mathrm{mg} / \mathrm{g}$ of the TA equivalent of total tannin content in ethanolic extract of Codiaeum variegatum. Saponin is the high molecular weight compound in which sugar molecules get combined with steroid glycone and triterpene. Therapeutically, saponins are very potent as they have shown anti-cancer and hypolipidemic activity. They can also react with cholesterol-rich plasma membranes of different cancerous cells and limit their proliferation [44]. Saponin isolated from EN leaf contains euphol as the main constituent. The saponin possesses great in vitro antioxidant and hemolytic activity, but it lacks antibacterial activity up to $10 \mathrm{mg} / \mathrm{ml}$ of concentration [17]. However, Sagbo et al. [45] reported that the content of saponin was higher when compared to the present report in Brachylaena ilicifolia (13.3 $\pm 0.58 \mathrm{mg} / \mathrm{g})$ and Brachylaena elliptica $(34.3 \pm$ $0.57 \mathrm{mg} / \mathrm{g}$ ). Similarly, El-Amier et al. [46] reported a high level of saponin content $(29.14 \mathrm{mg} / \mathrm{g})$ in the case of Euphorbia retusa (Forssk.). Plant phenolics are the broadest group of secondary metabolites in the plant kingdom. These phytocompounds have received a lot of attention as a potent natural antioxidant due to their ability to act as both metal chelator and radical scavengers. Therefore, it is advantageous to evaluate the number of phenolics in the plant samples chosen for the work [39]. However, VegaKuiz et al. [47] reported that the amount of total phenolic content in Jatropha cinerea $(82.65 \pm 1.65 \mathrm{mg} \mathrm{GAE} / \mathrm{g}$ in leaves and 62.02 $\pm 2.80 \mathrm{mg}$ GAE$/ \mathrm{g}$ in stem) was slightly higher when compared to the present report. Similarly, de Araújo et al. [48] mentioned a high level of phenolic content which ranged from 7.73 to $30.54 \mathrm{mg}$ GAE/g in Euphorbia tirucalli L. The content of phenol showed little variations in the case of Euphorbia antiquorum (1.68 mg GAE/g dried material), Euphorbia trigona (1.63 mg GAE/g dried material), and Euphorbia milii (3.61 mg GAE/g dried material), respectively [49]. Several studies have reported the potent biological activities of flavonoid groups such as anti-allergic, anticancer, anti-angiogenic, and antimicrobial, respectively [50]. It has been determined that flavonoids possess antioxidant activity due to their ability to chelate metal ions, such as iron and copper, to scavenge free radicals and to restrict the function of enzymes involved in a free radical generation
[51]. In this respect, Mustafa et al. [52] reported a higher level of flavonoid content from the methanolic extract $(17.9 \pm 0.32 \mathrm{mg}$ $\mathrm{QEq} / \mathrm{g}$ ) of Euphorbia helioscopia, whereas $9.26 \pm 3.50 \mathrm{mg} \mathrm{QE} / \mathrm{g}$ dry weight of flavonoid content was reported for Euphorbia hirta by Ismail et al. [53]. Similarly, Adam et al. [54] revealed $239.53 \pm 7.90$ $\mathrm{mg} \mathrm{QE} / \mathrm{g}$ of flavonoid content from methanolic extract of Euphorbia aegyptiaca. The results obtained from this study show that the level of phytocompounds evaluated in the extracts of the leaf, stem, latex, and bark of EN was relatively significant. The present study results also favor the results of previous studies including plants of the Euphorbiaceae family.

Antioxidants fight against these free radicals and protect against various types of diseases. They exert their action by protecting the antioxidant defense mechanism or by scavenging the reactive free radicals [55]. The antioxidant activity was determined through various assays for the leaf, stem, latex, and bark of EN.

$\mathrm{H}_{2} \mathrm{O}_{2}$ which is present in low concentrations in food, microorganisms, the human body, water, and air can easily decompose into water and oxygen to generate free hydroxyl radicals. These free radicals can cause damage to DNA and lipids [56]. The methanolic extract of EN leaf displayed the efficient scavenging activity than the other parts of EN. The FRAP assay estimated the reducing ability of EN extracts for ferric tripyridyltriazine complex to the colored ferrous tripyridyltriazine [57]. The results obtained from the present study revealed the significant reducing power in all extracts of EN. The DPPH assay measured the antioxidant capacity of the plant extracts which reduces the free radicals of DPPH to corresponding hydrazine with the change of color and reduction in absorbance at $517 \mathrm{~nm}$ [58]. In the present study, all the parts of EN contained a considerable amount of antioxidant activities according to the DPPH assay in a concentration-dependent manner. Thus, benzene extract of latex, aqueous extract of the stem, and methanolic extract of leaf and bark displayed the highest scavenging activity than the other solvent systems. Ferrozine is involved in the formation of a complex with ferrous ions $\left(\mathrm{Fe}^{2+}\right)$. In the availability of a chelating agent, this formation is inhibited. So, metal chelation assay measured the reduction in the formation of a ferrozine- $\mathrm{Fe}^{2+}$ complex in the presence of reference and test compound with a concomitant decrease in the violet color of the complex [59]. Data from the present investigations revealed a significant chelating power in all parts of EN. Nitric oxide assay involves the reaction of nitrite ions with Griess reagents to form azo dye [60]. Reduction in the generation of purple color azo dye determines the scavenging activity of EN extracts. All the parts of EN had a noticeable effect as a scavenger of nitric oxide radicals. The methanolic extract of leaf and aqueous extract of bark was found to be an efficient scavenger than the other extracts of stem and latex. Superoxide radical scavenging assay measured the ability of EN extracts to inhibit the formation of the formazan blue complex by scavenging the free radicals of superoxide which were generated in the presence of riboflavin-light-NBT (nitroblue tetrazolium). The result of this assay demonstrated better scavenging activity in the methanolic extract of leaf than the other extracts of different parts of EN [61]. In this respect, Pracheta et al. [62] determined the in vitro antioxidant activity through DPPH $(76.2 \pm 0.07 \%), \mathrm{H}_{2} \mathrm{O}_{2}(69.0 \pm 0.01 \%)$, and superoxide $(50.1 \pm 0.06 \%)$ assay from the hydroethanolic extract of EN leaf. Furthermore, Pracheta et al. [62] examined the ethanolic 
extract of EN leaf and reported the FRAP value of $149.2 \pm 0.05$ $\mu \mathrm{molFe}(\mathrm{II}) / \mathrm{g}$, respectively. The methanolic extract reported the highest scavenging activity as reported in the present study toward $\operatorname{ABTS}(689 \pm 25.94 \mu \mathrm{MTEq} / \mathrm{g}), \operatorname{FRAP}(758.9 \pm 25.1 \mu \mathrm{MFe}+2 / \mathrm{g})$, and $\mathrm{DPPH}\left(\mathrm{IC}_{50}\right.$ value $\left.=0.06 \pm 0.02 \mathrm{mg} / \mathrm{ml}\right)$ due to the presence of phenol and flavonoid in case of Euphorbia helioscopis [50]. Similarly, the ethyl acetate fraction of Euphorbia heterophylla was revealed to be the rich source of natural antioxidant with an $\mathrm{IC}_{50}$ value of 80.09 $\pm 0.87 \%$ for DPPH, $0.918 \pm 0.08 \%$ for total antioxidant assay, and $200.05 \pm 0.4 \mu \mathrm{M} / \mathrm{ml}$ for FRAP [63]. The aqueous, methanol, and ethyl acetate fraction of Euphorbia platyphyllos exhibited significant DPPH scavenging activity as reported in the present study than in the petroleum ether and diethyl ether extracts [64].

To correlate the present work results, Pearson's correlation analysis was carried out. Accordingly, a significant correlation was reported between the saponin, flavonoid, and flavonol compounds with antioxidant assays determined by $\mathrm{H}_{2} \mathrm{O}_{2}, \mathrm{DPPH}$, and $\mathrm{SO}$ assay. The high correlation suggested that the antioxidant capacity of leaf, stem, latex, and bark extracts could be possibly due to the presence of saponins, flavonoids, and flavonols. The results obtained from the present study were supported by various reports that described the important relationships between the phytocompounds and antioxidant assays [65-67].

\section{CONCLUSION}

Based on the responses in terms of scavenging activity, reducing power, and chelation of free metal, it was concluded that the species, EN, possesses potential antioxidant activity. The strong correlation between the contents of total saponin, flavonoid, and flavonols and radical scavenging activity indicates that these phytochemical constituents are major contributors to the antioxidant potential of this species. Therefore, this species can be utilized to derive drugs of antioxidant properties. However, further studies by in vitro and in vivo models are still required to confirm the antioxidant property of crude extract or the isolated compound from this medicinal plant against different diseases. Further toxicological and anticarcinogenic studies need to be conduct in order to manifest its potential as a natural anticarcinogenic drug.

\section{AUTHOR'S CONTRIBUTION}

All authors have read and approved the manuscript. The contribution of each author is mentioned below: PC: She is involved in the literature search and preparation of the manuscript. PJ: She is a Research guide and Assistant Professor and under her noble guidance the whole work is carried out. She is also giving training for ease of operation of sophisticated instrument and involved in the interpretation of data.

\section{ACKNOWLEDGEMENTS}

The authors would like to warmly thank Vice-Chancellor of Banasthali Vidyapith, Rajasthan for providing excellent research facilities and also acknowledge the Bioinformatics Center, Banasthali Vidyapith supported by DBT and DST for providing computation and networking support through the FIST and CURIE programs at the Department of Bioscience and Biotechnology, Banasthali Vidyapith, Rajasthan.

\section{FUNDING}

This research did not receive any specific grant from funding agencies in the public, commercial, or not-for-profit sectors.

\section{COMPETING INTERESTS}

This declaration is made by the authors of the articles: we have no known conflicting interests or personal connections that might have seemed to affect the research documented in this publication

\section{ETHICAL APPROVAL AND CONSENT TO PARTICIPATE}

This study does not involve experiments on animals or human subjects.

\section{LIST OF ABBREVIATIONS}

EN: Euphorbia neriifolia, $\mathrm{H}_{2} \mathrm{O}_{2}$ : Hydrogen peroxide, DPPH: 2,2-diphenyl-1-picrylhydrazyl, FRAP: Ferric-reducing antioxidant power assay, NO: Nitric oxide, SO: Superoxide, ROS: Reactive oxygen species, DM: Dry matter, TA: Tannic acid, QJ: Quillaja, QR: Quercetin, GLA: Gallic acid, RUT: Rutin, EDTA: Ethylenediaminetetraacetic acid, TT: Total tannin, TS: Total saponin, TP: Total phenol, TF: Total flavonoid, TFL: Total flavonol, ANOVA: Analysis of variance, LPE: Leaf petroleum ether, LBE: Leaf benzene, LCH: Leaf chloroform, LEA: Leaf ethyl acetate, LME: Leaf methanol, LAQ: Leaf aqueous, SPE: Stem petroleum ether, SBE: Stem benzene, SCH: Stem chloroform, SEA: Stem ethyl acetate, SME: Stem methanol, SAQ: Stem aqueous, LXPE: Latex petroleum ether, LXBE: Latex benzene, LXCH: Latex chloroform, LXEA: Latex ethyl acetate, LXME: Latex methanol, LXAQ: Latex aqueous, BPE: Bark petroleum ether, BBE: Bark benzene, BCH: Bark chloroform, BEA: Bark ethyl acetate, BME: Bark methanol, BAQ: Bark aqueous

\section{REFERENCES}

1. Aiyegoro OA, Okoh AI. Preliminary phytochemical screening and in vitro antioxidant activities of the aqueous extract of Helichrysum longifolium DC. BMC Complement Altern Med 2010;10:21. Available via https://www.biomedcentral.com/1472-6882/10/21

2. Guleria S, Tiku AK, Singh G, Koul A, Gupta S, Rana S. In vitro antioxidant activity and phenolic contents in methanol extracts from medicinal plants. J Plant Biochem Biotechnol 2012;22:9-15; http:// doi.org/10.1007/S3562-012-0105-6

3. Moriasi G, Ireri A, Ngugi MP. In vitro antioxidant activities of the aqueous and methanolic stem bark extracts of Piliostigma thonningii (Schum.). J Evid Based Integr Med 2020;http://doi. org/10.1177/2515690X20937988

4. Sahoos S, Ghosh G, Das D, Nayak S. Phytochemical investigation and in vitro antioxidant activity of an indigenous medicinal plant Alpinia nigra B.L. Burtt. Asian Pac J Trop Biomed 2013;3(11):871-6; http:// doi.org/10.1016/S2221-1691(13)60171-9.

5. Amudha M, Rani S. Evaluation of in vitro antioxidant potential of Cordia retusa. Indian J Pharm Sci 2016;78(1):80-6.

6. Kurutas EB. The importance of antioxidants which play the role in cellular response against oxidative/nitrosative stress: current state. Nutr J 2016;15:71; http://doi.org/10.1186/s12937-016-0186-5

7. Bouayed J, Bohn T. Exogenous antioxidants-double-edged swords in cellular redox state. Oxid Med Cell Longev 2010;3(4):228-37; http:// doi.org/10.4161/oxim.3.4.12858 
8. Abebiyi OE, Olayemi FO, Ning-Hua T, Guang-Zhi Z. In vitro antioxidant activity, total phenolic and flavonoid contents of ethanol extracts of stem and leaf of Grewia carpinifolia. Beni Suef Univ J Basic Appl Sci 2017;6:10-4; http://doi.org/10.1016/j.bjbas.2016.12.003.

9. Sofowora A, Ogunbodede E, Onayade A. The role and place of medicinal plants in the strategies for disease prevention. Afr J Trad Complement Altern Med 2013;10(5):210-29; http://doi.org/10.4314/ ajtcam.v.10i5.2

10. Guchu BM, Machocho AK, Mwihia SK, Ngugi NP. In vitro antioxidant activities of methanolic extracts of Caesalpinia volkensii Harms., Vernonia lasiopus O. Hoffm. and Acacia hockii De Wild. Evid Based Complement Altern Med 2020;http://doi.org/10.1155/2020/3586268

11. Tungmunnithum D, Thongboonyou A, Pholboon A, Yangsabai A. Flavonoids and other phenolic compounds from medicinal plants for pharmaceutical and medical aspects: an overview. Medicines (Basel) 2018;5(3):93; http://doi.org/10.3390/medicines5030093

12. Ghildiyal R, Prakash V, Chaudhary VK, Gupta V, Gabrani R. Phytochemicals as antiviral agents: recent updates. Plant-derived Bioactives 2020;12:279-95; http://doi.org/10.1007/978-981-15-17617-12

13. Pandey BP, Adhikari K, Pradhan SP, Shin HJ, Lee EK, Jung HJ. Invitro antioxidant, anti-cancer, and anti-inflammatory activities of selected medicinal plants from western Nepal. Future J Pharm Sci 2020;6:75; http://doi.org/10.1186/s43094-020-00107-0

14. Iqbal E, Abu Salim K, Lim LBL. Phytochemical screening, total phenolics and antioxidant activities of bark and leaf extracts of Goniothalamus velutinus (Airy Shaw) from Brunei Darussalam. J King Saud Univ Sci 2015;27:224-32; http://doi.org/10.1016/j. jksus.2015.02.003

15. Palit P, Mandal SC, Bhunia B. Total steroid and terpenoid enriched fraction from Euphorbia neriifolia Linn offer protection against nociceptive-pain, inflammation, and in vitro arthritis mode: an insight of mechanistic study. Int Immunopharmacol 2016;41:106-15; http:// doi.org/10.1016/j.intimp.2016.10.024

16. Rahman MB, Talukadar SN, Paul S, Rajbongshi S. Evaluation of pharmacognostical, phytochemical and ethnobotanical properties of Euphorbia neriifolia. Biojournal Sci Technol 2015a;2.

17. Bigoniya P, Rana AC. Pharmacological screening of Euphorbia neriifolia leaf hydro-alcoholic extract. J Appl Pharmacy 2010;1(2): $1-17$.

18. Choodej S, Pudham K. Cycloartane triterpenoids from the leaves of Euphorbia neriifolia. Phytochem Lett 2020;35:1-5; http://doi. org/10.1016/j.phytol.2019.10.005

19. Sharma V, Janmeda P, Paliwal R, Sharma S. Antihepatotoxic activity of Euphorbia neriifolia against N-nitrosodiethylamineinduced hepatocarcinogenesis in mice. J Chinese Integr Med 2012;10(11):1303-9.

20. Sharma V, Pracheta. Anti-carcinogenic potential of EN leaves and isolated flavonoids against N-Nitrosodiethylamine-induced renal carcinogenesis in mice. Indian J Biochem Biophys 2013;50:521-8.

21. Thorat BR, Bolli V. Review on Euphorbia neriifolia plant. Biomed J Sci Tech Res 2017;1(6); http://doi.org/10.26717/BJSTR.2017.01.000523

22. Chaudhary P, Janmeda P. Sehund: poison or medicine. Agric Food: E-Newletter 2021;3(4):254-6. E-ISSN: 2581-8317.

23. Sharma V, Pracheta. Extraction, isolation and identification of flavonoids from Euphorbia neriifolia leaves. Arab J Chem 2014;10(4):509-14; http://doi.org/10.1016/j.arabjc.2014.08.019

24. Haile M, Kang WH. Antioxidant activity, total polyphenol, flavonoid and tannin contents of fermented green coffee beans with selected yeast. Fermentation 2019;5(1),29; http://doi.org/10.3390/ fermentation5010029

25. Le AV, Parks SE, Nguyen MH, Roach PD. Optimisation of the microwave-assisted ethanol extraction of saponin from $\mathrm{Gac}$ (Momordica cochinchinensis Spreng.) seeds. Medicines (Basel) 2018;5(3):70; http://doi.org/10.3390/medicines5030070

26. Sankhalkar S, Vernekar V. Quantitative and qualitative analysis of phenolic and flavonoid content in Moringa oleifera Lam and
Ocimum tenuiflorum L. Pharmacogn Res 2016;8:16-21; http://doi org/10.4103/097-8490.171095

27. Rebaya A, Belghith SI, Baghdikian B, Leddet VM, Mabrouki F, Olivier E, et al. Total phenolic, total flavonoid, tannin content, and antioxidant capacity of Halimium halimifolium (Cistaceae). J Appl Pharm Sci 2014;5(1):052-7.

28. Zeghad N, Ahmed E, Belkhiri A, Heyden YV, Demeyer K. Antioxidant activity of Vitis vinifera, Punica granatum, Citrus aurantium and Opuntia ficus indica fruits cultivated in Algeria. Heliyon 2019;5(2019):e01575; http://doi.org/10.1016/j.heliyon.2019.e01575

29. Bhatti MS, Ali A, Ahmad A, Saeed A, Malik SA. Antioxidant and phytochemical analysis of Ranunculus arvensis L. extracts. BMC Res Notes 2015;8:279; http://doi.org/10.1186/s13104-015-1228-3

30. Fernandes RPP, Trindade MA, Toni FG, Lima CG, Pugine SMP, Munekata PES, et al. Evaluation of antioxidant capacity of 13 plant extracts by three different methods: cluster analyses applied for selection of the natural extracts with higher antioxidant capacity to replace synthetic antioxidant in lamb burgers. J Food Sci Technol 2015;53(1):451-60; https://doi.org/10.1007/s13197-015-1994-x

31. Sharma V, Paliwal R, Pracheta, Sharma S. Phytochemical analysis and evaluation of antioxidant activities of hydro-ethanolic extract of Moringa olifera Lam. Pods. J Pharm Res 2011;4(2):554-7.

32. Bariş D, Kizil M, Aytekin C, Kizil G, Yavuz M, Çeken B, et al. In vitro antimicrobial and antioxidant activity of ethanol extract of three Hypericum and three Achillea spices from Turkey. Int J Food Properties 2011;14(2):339-55; http://doi.org/10.1080/10942910903189256

33. Corpuz MJAT, Osi MO, Santiago LA. Free radical scavenging activity of Sargassum siliquosum J.G. Agardh. Int Food Res J 2013;20(1):2917; http://www.ifrj.upm.edu.my/20\%20(01)\%

34. Yang X-M, Yu W, Ou Z-P, Ma H-L, Liu W-M, Ji X-J. Antioxidant and immunity activity of water extract and crude polysaccharides from Ficus carica L. Fruit. Plant Foods for Human Nutr 2009;64:167-73.

35. Shad AA, Ahmad S, Ullah R, AbdEl-Salam NM, Fouad H, Ur Rehman $\mathrm{N}$, et al. Phytochemical and biological activities of four wild medicinal plants. Sci World J 2014;857363; http://doi.org/10.1155/2014/857363

36. Hussein RA, El-Anssary AA. Plant secondary metabolites: the key drivers of the pharmacological actions of medicinal plants. In: Builders PF (ed.). Herbal medicine, IntechOpen, London, UK, 2018; http://doi. org/10.5772/intechopen.76139

37. Idris OA, Wintola OA, Afolayan AJ. Phytochemical and antioxidant activities of Rumex crispus L. in treatment of gastrointestinal helminths in Eastern Cape Province, South Africa. Asian Pac J Trop Biomed 2017;7(12):1071-8; http://doi.org/10.1016/j.apjtb.2017.10.008

38. Sharma V, Aggarwal A. Physiochemical and antioxidant activity of methanol and hydromethanol extract of aerial parts of Indigofero tinctoria Linn. Indian J Pharm Sci 2015;77(6):729-34.

39. Pracheta, Sharma V, Paliwal R, Sharma S. Preliminary phytochemical screening and in vitro antioxidant potential of hydro-ethanolic extract of Euphorbia neriifolia. Int J PharmTech Res 2011;3(1):124-32.

40. Félix-silva J, Giordani RB, da Silva-Jr AA, Zucolotto SM, FernandesPedrosa MDF. Jatropha gossypiifolia L. (Euphorbiaceae): a review of traditional uses, phytochemistry, pharmacology, and toxicology of this medicinal plant. Evid Based Complement Altern Med 2014;369204; $\mathrm{http}: / /$ doi.org/10.1155/2014/369204

41. Khattak U, Ullah R, Khan SA, Barkatullah, Ullah S, Saima. Pharmacognostic evaluation and analgesic efficacy of ethanolic extract of Euphorbia dracunculoides L. Pharmacogn J 2017;9(5):644 53; http://doi.org/10.5530/pj.2017.5.102

42. Würger G, McGaq LJ, Eloff JN. Tannin content of leaf extracts of 53 trees used traditionally to treat diarrhoea is an important criterion in selecting species for further work. South Afr J Bot 2014;90:114-7; http://doi.org/10.1016/j.sajb.2013.11.003

43. Labu ZK, Laboni FR, Al Mamun MA, Howlader MSI. Antidiarrhoeal activity and total tannin content of ethanolic leaf extract of Codiaeum variegatum. J Pharm Sci 2015;14(1):87-90. 
44. Somit D, Priyankar D, Kumar CT. Quantification and correlation of the bioactive phytochemicals of Croton bonplandianum leaves of sub-Himalayan region of West Bengal. Asian J Pharm Clin Res 2013;6(3):142-7.

45. Sagbo IJ, Afolayan AJ, Bradley G. Antioxidant, antibacterial and phytochemical properties of two medicinal plant against the wound infecting bacteria. Asian Pac J Trop Biomed 2017;7(9):817-25; http:// doi.org/10.1016/j.apjtb.2017.08.009

46. El-Amier Y, Al-Hadithy ON, Fahmy AA, El-Eraky TE, El-Afify SM, Elagami SA, et al. Euphorbia retusa (Forssk.) a promising source for bioactive compound in biomedical and agriculture applications. Plant Arch 2021;21(1):23-31; http://doi.org/10.51470/ PLANTARCHIVES.2021.v21.no1.004

47. Vega-Ruiz YC, Hayano-Kanashiro C, Gámez-Meza N, Medina-Juárez LA. Determination of chemical constituents and antioxidant activities of leaves and stem from Jatropha cinerea (Ortega) Müll. Arg and Jatropha cordata (Ortega) Müll. Arg. Plants. 2021;10:212; http://doi. org/10.3390/plants10020212

48. de Araújo KM, de Lima A, Silva JDN, Rodrigues LL, Amorim AGN, Quelemes PV, et al. Identification of phenolic compounds and evaluation of antioxidant and antimicrobial properties of Euphorbia tirucalli L. Antioxidants 2014;3:159-75; http://doi.org/10.3390/ antiox3010159

49. Gapuz MCD, Besagas RL. Phytochemical profiles and antioxidant activities of leaf extracts of euphorbia species. J Biodivers Environ Sci 2018;12(4):59-65.

50. Ali Alabri TH, Salim Al Musalami AH, Hossain MA, Weli AM, AlRiyami Q. Comparative study of phytochemical screening, antioxidant and antimicrobial capacities of fresh and dry leaves crude plant extracts of Datura metel L. J King Saud Univ Sci 2014;26(3):237-43; https://doi.org/10.1016/j.jksus.2013.07.002

51. Mondal M, Hossain MS, Das N, Khalipha ABR, Sarkar AP, Islam MT, et al. Phytochemical screening and evaluation of pharmacological activity of leaf methanolic extract of Colocasia affinis Schott. Clin Phytosci 2019;5; http://doi.org/10.1186/s40816-019-0100-8

52. Mustafa I, Faisal MN, Hussain G, Muzaffar H, Imran M, Ijaz MU, et al. Efficacy of Euphorbia helioscopia in context to a possible connection between antioxidant and antidiabetic activities: a comparative study of different extracts. BMC Complement Med Ther 2021;21:62; http:// doi.org/10.1186/s12906-021-03237-x

53. Ismail A, Mohamed M, Kwei YF, Yin KB. Euphorbia hirta methanolic extract displays potential antioxidant activity for the development of local natural products. Pharmacogn Res 2019;11(1):78-85; http://doi. org/10.4103/pr.pr_113_18

54. Adam OAO, Abadi RSM, Ayoub AMH. Antioxidant activity, total phenolic and flavonoid contents and cytotoxic activity of Euphorbia aegyptiaca. J Drug Deliv Ther 2020;10(2); http://doi.org/10.22270/ jddt.v.10i2.3911

55. Khatoon M, Islam E, Islam R, Rahman AA, Khurshid Alam AHM, Khondkar $\mathrm{P}$, et al. Estimation of total phenol and in vitro antioxidant activity of Albizia procera leaves. BMC Res Notes 2013;6; http://doi. org/10.1186/1756-0500-6-121

56. Saeed N, Khan MR, Shabbir M. Antioxidant activity, total phenolic and total flavonoid contents of whole plant extracts Torilis leptophylla L. BMC Complement Altern Med 2012;12:221. Available via https:// www.biomedcentral.com/1472-6882/12/221
57. Irshad M, Ahmad I, Mehdi SJ, Goel HC, Rizvi MMA. Antioxidant capacity and phenolic content of the aqueous extract of commonly consumed cucurbits. Int J Food Properties 2013;17(1):179-86; http:// doi.org/10.1080/10942912.2011.619025

58. Rahman MM, Islam MB, Biswas M, Alam AHMK. In vitro antioxidant and free radical scavenging activity of different parts of Tabebuia pallida growing in Bangladesh. BMC Res Notes 2015;8:621; http:// doi.org/10.1186/s13104-015-1618-6

59. Hazra B, Biswas S, Mandal N. Antioxidant and free radical scavenging activity of Spondias pinnata. BMC Complement Altern Med 2008;8:63; http://doi.org/10.1186/1472-6882-8-63

60. Senguttuvan J, Paulsamy S, Karthika K. Phytochemical analysis and evaluation of leaf and root parts of the medicinal herb, Hypochaeris radicata $\mathrm{L}$. for in vitro antioxidant activities. Asian Pac J Trop Biomed 2014;4(Suppl 1):S359-67; http://doi.org/10.12980/apjtb.4.2014c1030

61. lloki-Assanga SB, Lewis-Luján LM, Lara-Espinoza CL, Gil-Salido AA, Fernandez-Angulo D, Rubio-Pino JL, et al. Solvent effects on phytochemical constituent profilers and antioxidant activities, using four different extraction formulations for analysis of Bucida buceras L. and Phoradendron californicum. BMC Research Notes 2015;8:396; http://doi.org/10.1186/s13104-015-1388-1

62. Pracheta, Sharma V, Paliwal R, Sharma S. In vitro free radical scavenging and antioxidant potential of ethanolic extract of Euphorbia neriifolia Linn. Int J Pharm Pharm Sci 2011;3(1):238-42.

63. Abbasi MA, Saleem H, Ur-Rehman A, Riaz T, Ajaib M. Determination of antioxidant activity and phytoconstituent screening of Euphorbia heterophylla Linn. Br J Pharm Res 2013;3(2):202-16.

64. Aslantürk OS, Celik TA. Antioxidant, cytotoxic and apoptotic activities of extracts from medicinal plant Euphorbia platyphyllos L. J Med Plants Res 2013;7(19):1293-304.

65. Granato D, Shahidi F, Wrolstad R, Kilmartin P, Melton LD, Hidalgo FJ, et al. Antioxidant activity, total phenolics, and flavonoids contents: should we ban in vitro screening methods? Food Chem 2018;264:4715; http://doi.org/10.1016/j.foodchem.2018.04.012

66. Lasano NF, Ramli NS, Hamid AH, Karim R, Dek MSP, Shukri R. Effects of different extraction solvents on polyphenols and antioxidant capacity of peel, pulp, and seed kernel of kuini (Mangifera odorata). Orient Pharm Exp Med 2019;19:277-86; http://doi.org/10.1007/ s13596-019-00383-z

67. Muniyandi K, George E, Sathyanarayanan S, George BP, Abrahamse $\mathrm{H}$, Thamburaj S, et al. Phenolics, tannins, flavonoids and anthocyanins contents influenced antioxidant and anticancer activities of Rubus fruits from Western Ghats, India. Food Sci Hum Wellness 2019;8(2019): 73-81; http://doi.org/10.1016/j.fshw.2019.03.005

How to cite this article: Chaudhary P, Janmeda P. Quantification of phytochemicals and in vitro antioxidant activities from various parts of Euphorbia neriifolia Linn. J Appl Biol Biotech 2022; 10(02):133-145. 